\title{
Albian and Cenomanian ammonites from the island of Bornholm (Denmark)
}

\author{
WILLIAM JAMES KENNEDY, JAKE MICHAEL HANCOCK AND WALTER KEGEL CHRISTENSEN
}

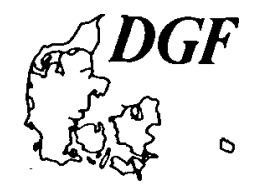

\begin{abstract}
Kennedy, W. J., Hancock, J. M. \& Christensen, W. K.: Albian and Cenomanian ammonites from the island of Bornholm (Denmark). Bull. geol. Soc. Denmark, vol. 29, pp. 203-244, Copenhagen, January 26th, 1981. https://doi.org/10.37570/bgsd-1980-29-13

The ammonite faunas from the Arnager Greensand and its conglomerate on the island of Bornholm (Denmark) are revised. Three time intervals are represented in the phosphatic conglomerate. The ammonites from the primary nodules represent two time intervals in the Lower Albian (Leymeriella tardefurcata and Douvilleiceras mammilatum Zones). The ammonites from the phosphatized matric of the secondary nodules are assigned to the Lower Cenomanian (Mantelliceras saxbii and/or $M$. dixoni Zones). The Arnager Greensand sensu stricto is low in the Middle Cenomanian (Turrilites costatus Zone) on the basis of ammonites and planktic foraminifers. The transgressive history of the Mid-Cretaceous on the island of Bornholm is outlined.
\end{abstract}

W. J. Kennedy, Geological Collections, University Museum, Oxford OXI 3PW, England. J. M. Hancock, Department of Geology, King's College, Strand, London WC2R 2LS, England. W. K. Christensen, Geological Museum, Oster Voldgade 5-7, DK-1350 Copenhagen, Denmark. September 18th, 1980. This paper is a contribution to IGCP-project Mid-Cretaceous Events.

\section{Introduction}

More than fifty years have passed since Ravn $(1916,1925)$ monographed the ammonites from the Amager Greensand and its phosphatic conglomerate on the south coast of the island of Bornholm. Ravn also gave a detailed description of the greensand, its conglomerate, and the lower boundary of the formation. Ravn considered the conglomerate to be a basal conglomerate for the marine Cretaceous, and he defined the conglomerate as the base of the Amager Greensand.

The aim of the present paper is to revise the ammonite faunas from the Arnager Greensand and its conglomerate, because (1) rich ammonite faunas from the mid-Cretaceous are not found elsewhere in the Baltic area, northern Germany or Scandinavia, and (2) the ammonite faunas provide important information on the transgressive history of the mid-Cretaceous in the Fennoscandian Border Zone. Moreover, the boundary between the Cenomanian Arnager Greensand and the Early Cretaceous Jydegaard Formation, earlier referred to the Wealden needs discussion. Comments are also made on the foraminifers from the Amager Greensand.

\section{General geological setting}

The island of Bornholm in the Baltic Sea is a horst in the Fennoscandian Border Zone: that is the marginal area between the stable Pre-Cambrian Baltic Shield and the generally subsiding Permo-Mesozoic Danish Embayment which forms part of the Danish-Polish Trough (fig. 1), and can be followed from northem Jutland across

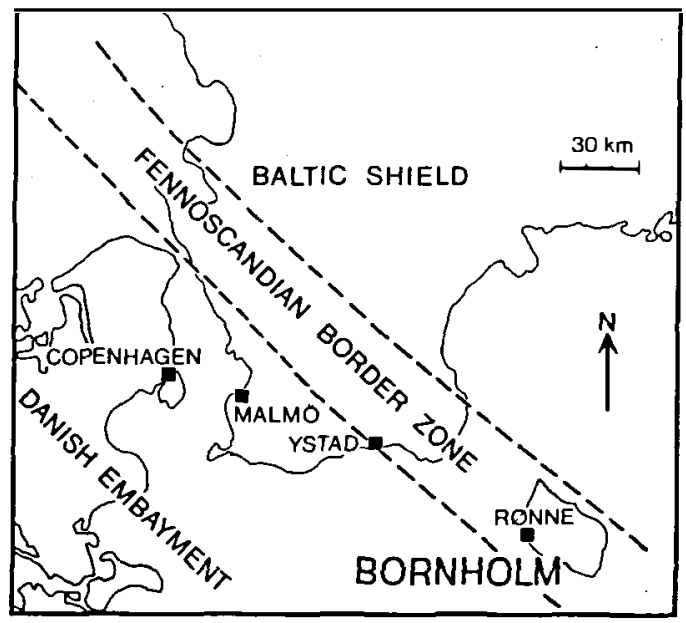

Fig. 1. Map showing the location of the island of Bornholm and the approximate location of the Fennoscandian Border Zone. 
Scania and Bornholm to Poland. This marginal area is characterized by graben and horst structures trending NW-SE and is crossed by faults with a mean direction NNE-SSW, creating a mosaic of tilted blocks. The Border Zone has also been discussed under other names, viz. Tornquist Line, Tornquist-Jentzsch Line or TornquistTeissyre Line; see a recent review by Baartman \& Bruun Christensen, 1975.

The northern two-thirds of the island of Bornholm consists of Pre-Cambrian granite and gneiss, and Mesozoic sediments are found to the south in down-faulted areas (fig. 2). Mesozoic sediments are also found in a small down-faulted area at Nyker.

\section{Arnager Greensand}

The Cenomanian Arnager Greensand has been found in three down-faulted areas on the island of Bornholm: (1) between Grødby $\AA$ and Lxså, (2) in the Nyker area, and (3) between Madsegrav and Arnager on the south coast of Bornholm (Gry 1960). At the last locality the Arnager Greensand crops out in low sea cliffs. The general dip of this fault block is $6^{\circ}$ towards SW. However, near or at the coast the dip might be slightly greater, and at Madsegrav itself the Arnager Greensand dips $12-13^{\circ}$ towards SW (Ravn 1916, 1925).

The Arnager Greensand is a loose, poorly sorted, glauconitic quartz sand deposit that rests with a slight angular uncorformity on the Early Cretaceous Jydegaard Formation (Gry 1960). The latter formation was earlier referred to the Wealden, but according to Bruun Christensen (1972) it might be Valanginian-Hauterivian. The thickness of the Arnager Greensand is estimated to be ca. $85 \mathrm{~m}$ (E. Stenestad, pers. comm. 1977). The basal part of the Arnager Greensand is ex-

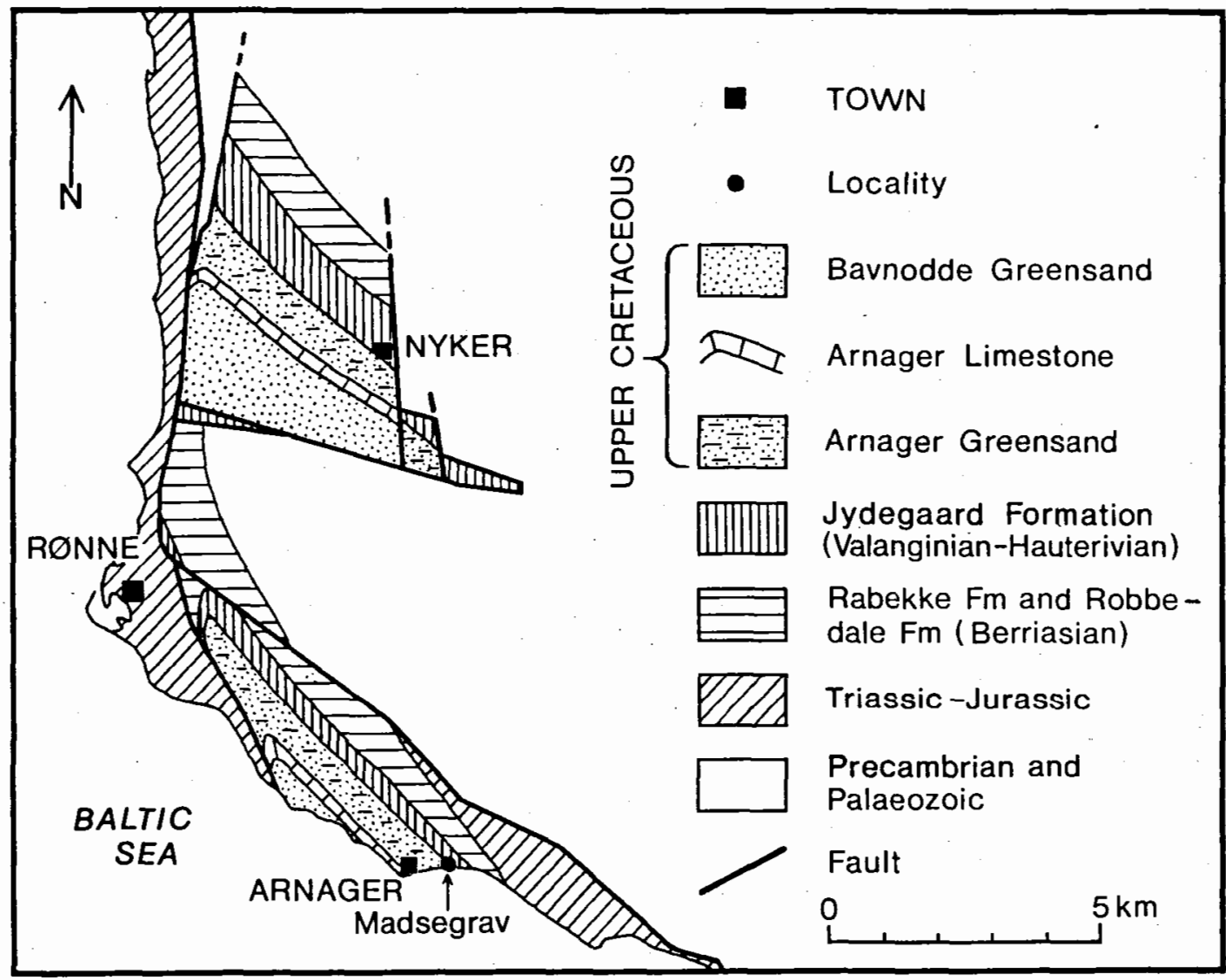

Fig. 2. Geological map of southwestern part of the island of Bornholm showing the lithostratigraphical formations at the base of the Quaternary (after Gry 1960). 
posed immediately west of the Madsegrav creek, and the topmost part of the formation can be seen at the beach approximately $110-130 \mathrm{~m}$ west of Arnager. Here the Arnager Greensand is overlain by the Arnager Limestone, which was referred to the late Coniacian by Douglas \&
Rankin (1969), Stenestad (1972) and Christensen (1973). From a hitherto unknown horizon in the upper part of the Arnager Greensand (ca. 4-5 $\mathrm{m}$ below the basal conglomerate of the Arnager Limestone) a sample was collected in 1975 by WKC during a temporary excavation for a

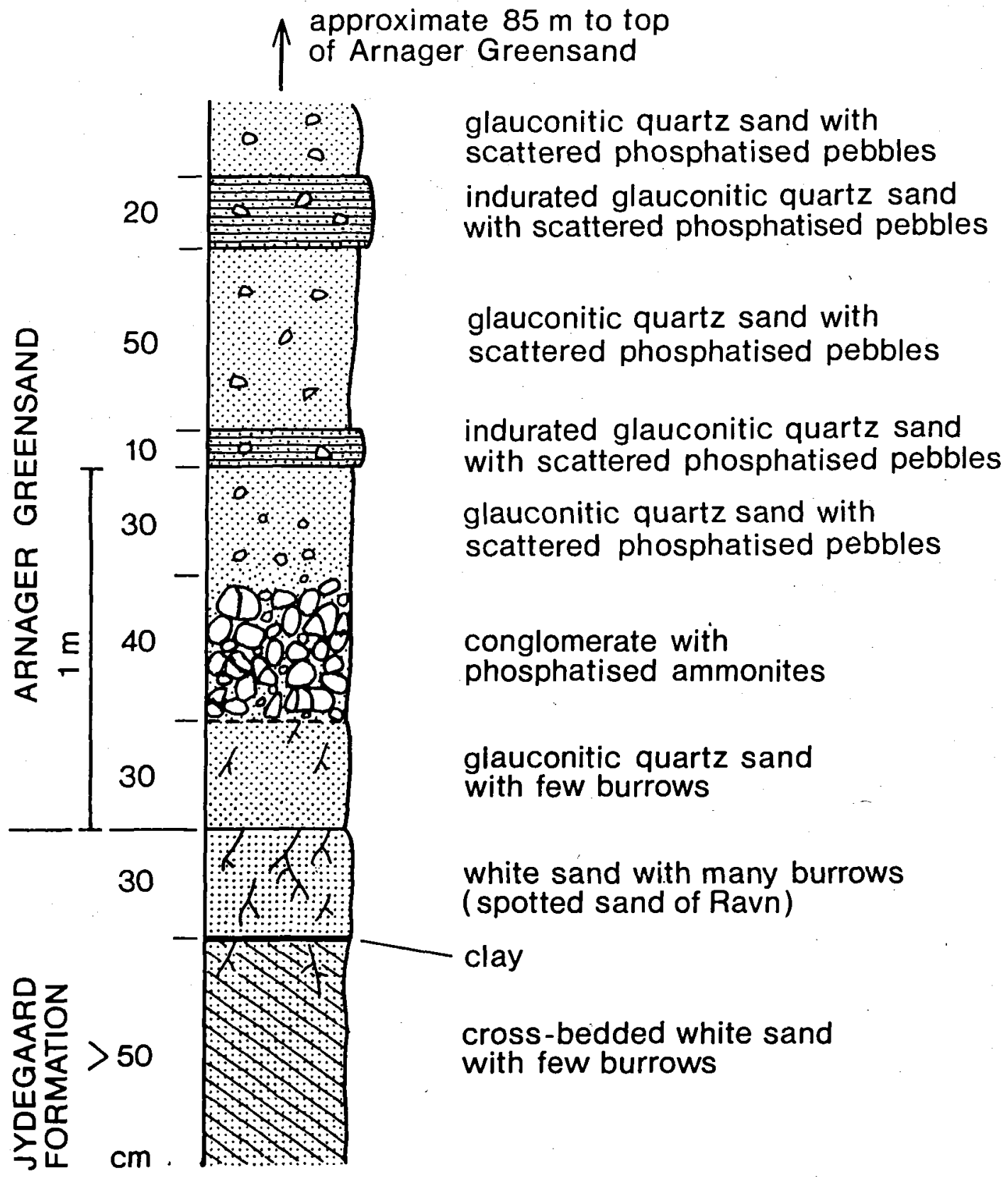

Fig. 3. Section of the boundary between the Jydegaard Formation of Valanginian-Hauterivian age and the overlying Arnager Greensand Formation at Madsegrav. The phosphatized ammonites came from the conglomerate, and the unphosphatized ammonites came by and large from the two indurated glauconitic quartz sand beds. 
sewerage plant. This sample has yielded stratigraphically diagnostic foraminifers (Hart 1979; see below).

A section of the boundary between the fresh and brackish water Jydegaard Formation and the basal part of the Arnager Greensand at Madsegrav, as measured by WKC in 1977, is shown in fig. 3 (se also Bromley 1979, fig. 6). The upper part of the Jydegaard Formation consists of cross-bedded white sand with a few thalassinoid burrows. This layer is overlain by a $30 \mathrm{~cm}$ thick bed of white sand which has been heavily biotubated by thalassinoid burrows. The burrows are infilled by the overlying glauconitic quartz sand, resulting in a spotted appearance of the sand ('spotted sand' of Ravn 1916). Upon the spotted sand follows the Arnager Greensand which starts with a $30 \mathrm{~cm}$ thick glauconitic quartz sand without phosphatic pebbles. This sand has yielded a few foraminifers without stratigraphical value $(E$. Stenestad, pers. comm. 1977) and shark-teeth; Bromley (1979) records 'Rhynchonella' sigma and Avellana incrassata. The glauconitic quartz sand is succeeded upwards by a $40 \mathrm{~cm}$ thick conglomerate with complexly built phosphatized pebbles and cobbles (hiatus concretions). The conglomerate is followed upwards by a loose glauconitic quartz sand with two layers of indurated glauconitic quartz sand. The greensand above the conglomerate also contains scattered phosphatized pebbles.

It should be stressed at this point that the boundary between the Arnager Greensand and the Jydegaard Formation is placed at a lower level in the section than Ravn did $(1916,1925)$, because it seems more natural to include the glauconitic quartz sand below the conglomerate in the Arnager Greensand.

The conglomerate was described in detail by
Ravn (1925). It consists mainly of phosphatic nodules ranging in size from $1 \mathrm{~cm}$ up to $30 \mathrm{~cm}$. Lower Cambrian sandstone and quartzite, and Jurassic or Early Cretaceous lignite were also reported from the conglomerate. Ravn recognized two generations of phosphatic nodules in the conglomeratic pebble bed: (1) primary nodules consisting largely of phosphatized glauconitic sandstone, and (2) secondary nodules that are built up by primary nodules cemented together by a matrix of brownish phosphatized glauconitic sand. The nodules often carry encrusting animals. The conglomeratic pebble and cobble bed was reported from several outcrops and shallow borings on the southern fault block (between Madsegrav and Stampe $\AA$ ) and the thickness varies between 18-55 cm, with a mean thickness of 37 cm (Ravn 1925).

\section{Age of the Arnager Greensand faunas}

Ravn (1925) referred the fauna from the primary nodules ('Hoplites Horizons' of Ravn) to the Lower Albian (tardefurcata-regularis Zone) and the fauna from the matrix of the secondary nodules ('Schloenbachia Horizon' of Ravn) to the Upper Albian and Lower Cenomanian. The Arnager Greensand could be younger. Ravn arrived at these conclusions on the basis of mollusks, mainly ammonites. Rosenkrantz (1945), on the basis of a single specimen of Acanthoceras, Birkelund (1957), on the basis of the belemnite $A C$ tinocamax primus, and Douglas \& Rankin (1967), on the basis of planktic foraminifers, confirmed Ravn's dating of the Arnager Greensand sensu stricto.

Our revision of Ravn's and Rosenkrantz' ammonites is as follows:
RAVN, 1916 and 1925

Kossmatella? sp.

Desmoceras Beaudanti Brogn. sp.

Desmoceras (Puzosia)

Mayorianum d'Orb. sp. (pars.)

Hoplites auritus Sow. sp.?

\section{Revised determinations}

Sonneratia spp.

Cleoniceras spp.; Anadesmoceras cf. strangulatum Casey

Sonneratia spp. indet.

Otohoplites group of auritiformis Spath 
Hoplites (Leymeriella) regularis Brug. sp.

Parahoplites Milletianus d'Orb. sp.

Parahoplites Steinmanni Jacob

Parahoplites Hitzeli Jacob

Parahoplites Puzosianus d'Orb. sp.

Parahoplites n.sp.

Sonneratia Baylei Jacob

Sonneratia Parenti Jacob

Sonneratia Dutempleana d'Orb. sp.

Schloenbachia Varians Sow. sp.

Schloenbachia coupei Brong. sp.

ROSENKRANTZ, 1945

Acanthoceras aff. sherboni Spath
Leymeriella sp.; L. (Neoleymeriella) regularis (Brugière); Sonneratia? sp.

Hypacanthoplites milletioides Casey; $H$. spp. indet.

Pseudosonneratia sp.; P. cf. occidentalis pluricostata Casey; Sonneratia sp.

Leymeriella (Epileymeriella) hitzeli (Jacob)

Protohoplites (Hemisonneratia) cf. puzosianus (d'Orbigny)

Sonneratia kitchini Spath; S. sp.

Cleoniceras sp.; Anadesmoceras costatum Casey; A. group of subbaylei Spath

Otohoplites guersanti (d'Orbigny); Cleoniceras sp.

\section{Sonneratia cf. rotator Casey}

Schloenbachia spp., mostly indeterminate, but include definite $S$. varians and $S$. coupei, although determined specimens do not correspond to Ravn's division of the material.

Revised determination

Acanthoceras rhotomagense (Brongniart) sussexiense (Mantell).
Table 1 shows plots of the possible and probable age indications of the Albian elements of this assemblage. The fauna of the 'Hoplites Horizon' is entirely of Lower Albian age in our view, with representatives of the Leymeriella regularis Subzone at the top of the $L$. tardefurcata Zone, the succeeding Sonneratia kitchini Subzone at the base of the Douvilleiceras mammilatum Zone, and the two highest subzones of the D. mammilatum Zone, those of Otohoplites raulinianus and Protohoplites (Hemisonneratia) puzosianus definitely proven by short-ranging species (see table 2). The Hypacanthoplites present, although long-ranging, suggest the $H$. milletioides Subzone, so that two time intervals appear to be represented in the assemblage. There is no unequivocal evidence for the late Aptian or earliest Albian, nor for the Cleoniceras floridum Subzone, although some of the specimens deter- mined to generic level only could conceivably come from these levels.

The phosphatic secondary nodules are all Lower Cenomanian, probably coming from the Mantelliceras saxbii and/or Mantelliceras dixoni Zones (table 3). Neither of the phosphatic ammonite assemblages shows any evidence of Late Albian.

It is unfortunate that the unphosphatized ammonites from the main thickness of the Arnager Greensand do not have their exact horizons recorded, but their preservation indicates the hard beds near the base of the Greensand (see fig. 3). The Turrilites scheuzerianus, Acanthoceras rhotomagense sussexiense and nearly all the Schloenbachia are of Middle Cenomanian aspect, the Schloenbachia suggesting the $T$. costatus Zone (lower Middle Cenomanian). Two of the Schloenbachia may be lower Cenomanian, but if 
Table 1. Plot of the possible and probably age indications of the Albian ammonites from the phosphatized conglomerate in the lower part of the Arnager Greensand.

\begin{tabular}{|c|c|c|c|c|c|c|c|c|c|}
\hline Zone & $\begin{array}{l}\text { Hyp } \\
\text { jaco }\end{array}$ & & $\begin{array}{l}\text { Ley! } \\
\text { tard }\end{array}$ & $\begin{array}{l}\text { eriel } \\
\text { furc: }\end{array}$ & & & $\begin{array}{l}\text { uvillei } \\
\text { mmila }\end{array}$ & $\begin{array}{l}\text { eras } \\
\text { tum }\end{array}$ & \\
\hline Subzies & . & 总 & 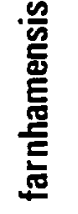 & : & 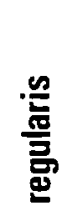 & 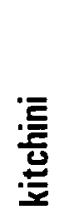 & $\underset{\underline{\underline{z}}}{\underline{\underline{\underline{b}}}}$ & 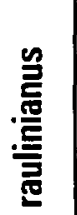 & 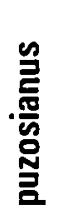 \\
\hline $\begin{array}{l}\text { Hypacanthoplites } \\
\text { milletioides }\end{array}$ & & & -- & & & & & & \\
\hline Hypacanthoplites spp. & - & 一. & - & - - & & & & & \\
\hline $\begin{array}{l}\text { P. (Hemisonneratia) } \\
\text { cf.puzosianus }\end{array}$ & & & & & & & & & \\
\hline $\begin{array}{l}\text { Otohoplites gr. } \\
\text { auritiformis }\end{array}$ & & & & & & & & & \\
\hline $\begin{array}{l}\text { Otohoplites } \\
\text { guersanti }\end{array}$ & & & & & & & & & \\
\hline $\begin{array}{l}\text { Sonneratia } \\
\text { kitchini }\end{array}$ & & & & & & & & & \\
\hline $\begin{array}{l}\text { Sonneratia } \\
\text { cf.rotator }\end{array}$ & & & & & & & & & \\
\hline $\begin{array}{l}\text { Sonneratia } \\
\text { perinflata }\end{array}$ & & & & & & & & & \\
\hline $\begin{array}{l}\text { Sonneratia } \\
\text { sp. undetermined }\end{array}$ & & & & & & & & & \\
\hline $\begin{array}{l}\text { Pseudosonneratia } \\
\text { sp. }\end{array}$ & & & & & & & & & \\
\hline $\begin{array}{l}\text { P.occidentalis } \\
\text { pluricostata }\end{array}$ & & & & & & & & & \\
\hline Cleoniceras sp. & & & & & & - - & - & - & \\
\hline $\begin{array}{l}\text { Anadesmoceras } \\
\text { costatum }\end{array}$ & & & & & & & & & \\
\hline $\begin{array}{l}\text { Anadesmoceras } \\
\text { cf. strangulatum }\end{array}$ & & & & & & & & & \\
\hline $\begin{array}{l}\text { Anadesmoceras } \\
\text { gr. subbaylei }\end{array}$ & & & & & & & & & \\
\hline $\begin{array}{l}\text { L.(Neoleymeriella) } \\
\text { regularis }\end{array}$ & & & & & & & & & \\
\hline $\begin{array}{l}\text { Leymeriolla } \\
\text { spp.undetermined }\end{array}$ & & & & & & & & & \\
\hline $\begin{array}{l}\text { L.(Epileymeriella) } \\
\text { hitzeli }\end{array}$ & & & & & & & & & \\
\hline
\end{tabular}


most of the ammonites have come from the hard beds very little of the Greensand can be older than Middle Cenomanian.

Hart (1979) has provided careful records of the foraminifera from the Arnager Greensand. He suggests that approximately $5 \mathrm{~m}$ of the Greensand above the conglomerate are still Lower Cenomanian with the benthic foraminiferid Lin-

Table 2. Standard ammonite zonation of the Upper Aptian and Albian (after Kennedy \& Hancock, 1978).

\begin{tabular}{|c|c|c|}
\hline SUBSTAGE & AMMONITE ZONES & AMMONITE SUBZONES \\
\hline \multirow[b]{2}{*}{ UPPER ALBIAN } & Stoliczkaia dispar & $\begin{array}{l}\text { Mortoniceras perinflatum } \\
\text { Stoliczkaia blancheti }\end{array}$ \\
\hline & Mortoniceras inflatum & $\begin{array}{l}\text { Mortoniceras altonense } \\
\text { Callihoplites aurites } \\
\text { Hysteroceras varicosum } \\
\text { Hysteroceras orbignyi } \\
\text { Dipoloceras cristatum }\end{array}$ \\
\hline \multirow{3}{*}{ MIDDLE ALBIAN } & Euhoplites Iautus & $\begin{array}{l}\text { Anahoplites daviesi } \\
\text { Euhoplites nitidus }\end{array}$ \\
\hline & Euhoplites Ioricatus & $\begin{array}{l}\text { Euhoplites meandrinus } \\
\text { Mojsisovicsia subdelaruei } \\
\text { Dimorphoplites niobe } \\
\text { Anahoplites intermedius }\end{array}$ \\
\hline & Hoplites (Hoplites) dentatus & $\begin{array}{l}\text { Hoplites spathi } \\
\text { Lyelliceras lyelli } \\
\text { Hoplites (Isohoplites) eodentatus }\end{array}$ \\
\hline \multirow[t]{2}{*}{ LOWER ALBIAN } & Douvilleiceras mammillatum & $\begin{array}{l}\text { Protohoplites puzosianus } \\
\text { Otohoplites raulinianus } \\
\text { Cleoniceras floridum } \\
\text { Sonneratia kitchini }\end{array}$ \\
\hline & Leymeriella tardefurcata & $\begin{array}{l}\text { Leymeriella regularis } \\
\text { Hypacanthoplites milletioides } \\
\text { Farnhamia farnhamensis }\end{array}$ \\
\hline UPPER APTIAN & Hypacanthoplites jacobi & $\begin{array}{l}\text { Hypacanthoplites anglicus } \\
\text { Hypacanthoplites rubricosus } \\
\text { Noloniceras nolani }\end{array}$ \\
\hline
\end{tabular}

Table 3. Standard ammonite zonation of the Cenomanian and Lower Turonian (after Kennedy \& Hancock, 1978).

\begin{tabular}{|l|l|l|}
\hline SUBSTAGE & CLASSIC AMMONITE ZONES & CURRENT AMMONITE ZONES \\
\hline LOWER TURONIAN & & Mammites nodosoides \\
\hline UPPER CENOMANIAN & Calycoceras naviculare & $\begin{array}{l}\text { Sciponoceras gracile } \\
\text { Eucalycoceras pentagonum/ } \\
\text { Calycoceras naviculare }\end{array}$ \\
\hline MIDDLE CENOMANIAN & ACanthoceras rhotomagense & $\begin{array}{l}\text { Acanthoceras jukesbrownei } \\
\text { Turrilites acutus } \\
\text { Turrilites costatus }\end{array}$ \\
\hline LOWER CENOMANIAN & Mantelliceras mantelli & $\begin{array}{l}\text { Mantelliceras gr. dixoni } \\
\text { Mantelliceras saxbi } \\
\text { Hypoturrilites carcitanensis }\end{array}$ \\
\hline
\end{tabular}


gulogavelinella jarzeva (Vasilenko). Most of the foraminifera from the main thickness of the Greensand indicate lower Middle Cenomanian. Most interestingly he has obtained from the top few metres of the Greensand at Arnager itself over a hundred specimens of Rotalipora reicheli Mornod. According to Hart this species in large numbers in south-east England and northern France embraces the boundary between the Zones of $M$. dixoni and $T$. costatus (see also van Hinte 1976). Therefore the foraminifera show that the top of the Greensand probably does not extend above the costatus Zone, low in the Middle Cenomanian. Almost all the Arnager Greensand is lower Middle Cenomanian.

\section{The transgressive history of the island of Bornholm in the Mid-Cretaceous}

In the present paper transgression means migration of the shoreline in a landward direction and regression is migration of the shoreline in a seaward direction irrespective of the nature of these shoreline migrations.

On the basis of the datings of the ammonites faunas from the phosphatic conglomerate and the Arnager Greensand the following history of the Mid-Cretaceous of the island of Bornholm is offered. In Barremian, Aptian or earliest Albian time the Cretaceous sea invaded the Bornholm area, the depositional environment changed from fresh and brackish water (Jydegaard Formation) to marine, and glauconitic quartz sand was laid down. During a regressive period in Middle and Late Albian time, glauconitic quartz sand of Early Albian age was deeply eroded and phosphatized. The possible absence of the Cleoniceras floridum Subzone might indicate a short-lived regression in the Lower Albian between the Sonneratia kitchini and Otohoplites raulinianus Subzones. During a renewed tranśgression in the Lower Cenomanian the primary phosphatic nodules were cemented together but during a regressive pulse at the transition between the Lower and Middle Cenomanian the sediment was again eroded and phosphatized and the secondary nodules were accumulated in the conglomeratic pebble and cobble bed at the base of the greensand of Early Middle Cenomanian age. After the deposition of the greensand followed a long regressive period spanning the interval Late
Middle Cenomanian to early Coniacian. This regressive period was followed by a transgression in the late Coniacian time when the Arnager Limestone was laid down.

The causes of transgression and regression in a specific area might be multiple; the most important being: (1) global eustatic sea level changes, (2) local or regional tectonic movements, and (3) rate of net deposition (see Curray 1964 and Donovan \& Jones 1979 for thorough discussion of transgression-regression processes). Global eustatic sea-level changes have been attributed to episodes of uplift and subsidence of oceanic ridges (see i.a. Cooper 1977, Matsumoto 1977 and Hancock \& Kauffman 1979 for Cretaceous eustatic cycles and Hallam 1978 for Jurassic cycles). On the other hand, Jeletzky (1978) is of the opinion that although eustatic sea-level oscillations undoubtedly did occur in the Cretaceous, the oscillations normally are overprinted by local, regional or even interregional tectonic movements of continental blocks.

The island of Bornholm is situated in the Fennoscandian Border Zone, and it might therefore be difficult to decide whether the transgressive-regressive history in the mid-Cretaceous was controlled by global eustatic sea-level changes or local block-faulting in the border zone. However, on the Baltic Shield north of the border zone there is evidence of an Albian-Cenomanian transgression, and the Ringkøbing-Fyn High also provides evidence for an Albian-Cenomanian transgressive pulse (cf. Christensen 1978).

Since the Albian/Cenomanian transgressive pulse has been recorded from the Danish Embayment, the Fennoscandian Border Zone and the Baltic Shield, it may well be that this transgressive event was related to a global eustatic rise of sea-level. The major hiatus recorded on the island of Bornholm between the Arnager Greensand and the Arnager Limestone accords with the widespread major regression that troughs late in the Turonian (Hancock \& Kauffman 1979). That the highest part of the Arnager Greensand may not extend above the Zone of Turrilites costatus could mean that sedimentation ceased at the mid-Cenomanian non-sequence of Hart \& Tarling (1977) and Carter \& Hart (1977). It is equally likely that erosion during the late Turonian regression removed any younger Cenomanian or earliest Turonian sediments. The 
transgression known from other regions of Europe that started in the latest Turonian apparently did not reach Bornholm until the Late Coniacian when the Arnager Limestone was deposited.

\section{Systematic Descriptions}

Provenance of the material

During the first world war it proved very difficult and even impossible to import phosphatic fertilizer, and the Danish State therefore decided to exploit the phosphate of the phosphatic conglomerate of the Arnager Greensand. Mining was started in 1919 at Madsegrav (fig. 2), but in the following year the mining was already stopped when it again became possible to import phosphate. During the quarrying of the phosphatic conglomerate, a large amount of ammonite-material was collected (Ravn 1925).

Most of the ammonites from the Arnager Greensand sensu stricto were also collected early in this century, and originate by and large from the lowermost part of the greensand (Ravn 1916).

The specimens figured by Ravn $(1916,1925)$ and earlier workers are in the type collection of the Geological Museum of the University of Copenhagen, filed as MMH, nos. 1539-1541, 2016-2021, 2023-2027 and 5163. The specimens figured in the present paper that have not been figured before are filed as MGUH, nos. 15127-15184. In addition, specimens that have not been figured carry the accession numbers of the museum with prefix MM.

\section{Mollusca}

Cephalopoda Cuvier, 1797

Ammonoidea Zittel, 1884

Lytoceratida Hyatt, 1889

Ancyloceratina Wiedmann, 1966

Turrilitaceae Meek, 1876

Turrilitidae Meek, 1876

Turrilites Lamarck, 1801

Type species: Turrilites costatus Lamarck, 1801 by original designation.

Remarks: Three subgenera have been recognized within this genus: $T$. (Turrilites), $T$. (Euturrilites) and T. (Mesoturrilites). Mesoturrilites is differentiated on the basis of the fusion of clavate tubercles on the lower part of the outer whorl face, whilst Euturrilites has continuous ribs only on the outer face during later growth. Most recent workers have accepted Mesoturrilites as a useful division, but regard Euturrilites as a synonum of Turrilites sensu stricto, a view followed here. See Reyment (1955), Kennedy (1971) and Juignet \& Kennedy (1977) for recent observations on the genus.

Turrilites scheuchzerianus Bosc, 1801

PI. 12, figs. 1a-c.

Synonymy: detailed synonymies are given by Diener (1925), Wiedmann (1962) and Juignet \& Kennedy (1977).

Material: MGUH 15127, from the Arnager Greensand near Madsegrav preserved in glauconitic sandstone with angular phosphatic clasts.

Description: The specimen consists of a distorted composite mould (and corresponding counterpart) of one and a half whorls. The maximum whorl height is $23.6 \mathrm{~m}$; the whorl section shows marked concave upper, and correspondingly convex lower whorl faces (concealed below the whorl suture in the complete specimen). The angulation between upper and outer whorl faces is sharp and acute, that with the lower obtuse. The upper outer flank is rounded and the outer face flattened.

There are 21-22 prorsiradiate ribs per whorl, arising at the upper whorl suture, where they are strong, even and rounded. These ribs extend across the upper third of the outer whorl face, and are interrupted across the middle of the face by a flat smooth band, to reappear low on the face, where they terminate just above the lower whorl suture. A narrow smooth band separates them from a distinct, continuous spiral ridge at the suture, whilst lower and upper whorl surfaces beneath the suture are quite smooth.

Remarks: For more than a century there has been a dichotomy of views on the nature of the relationship between forms like the present one - 


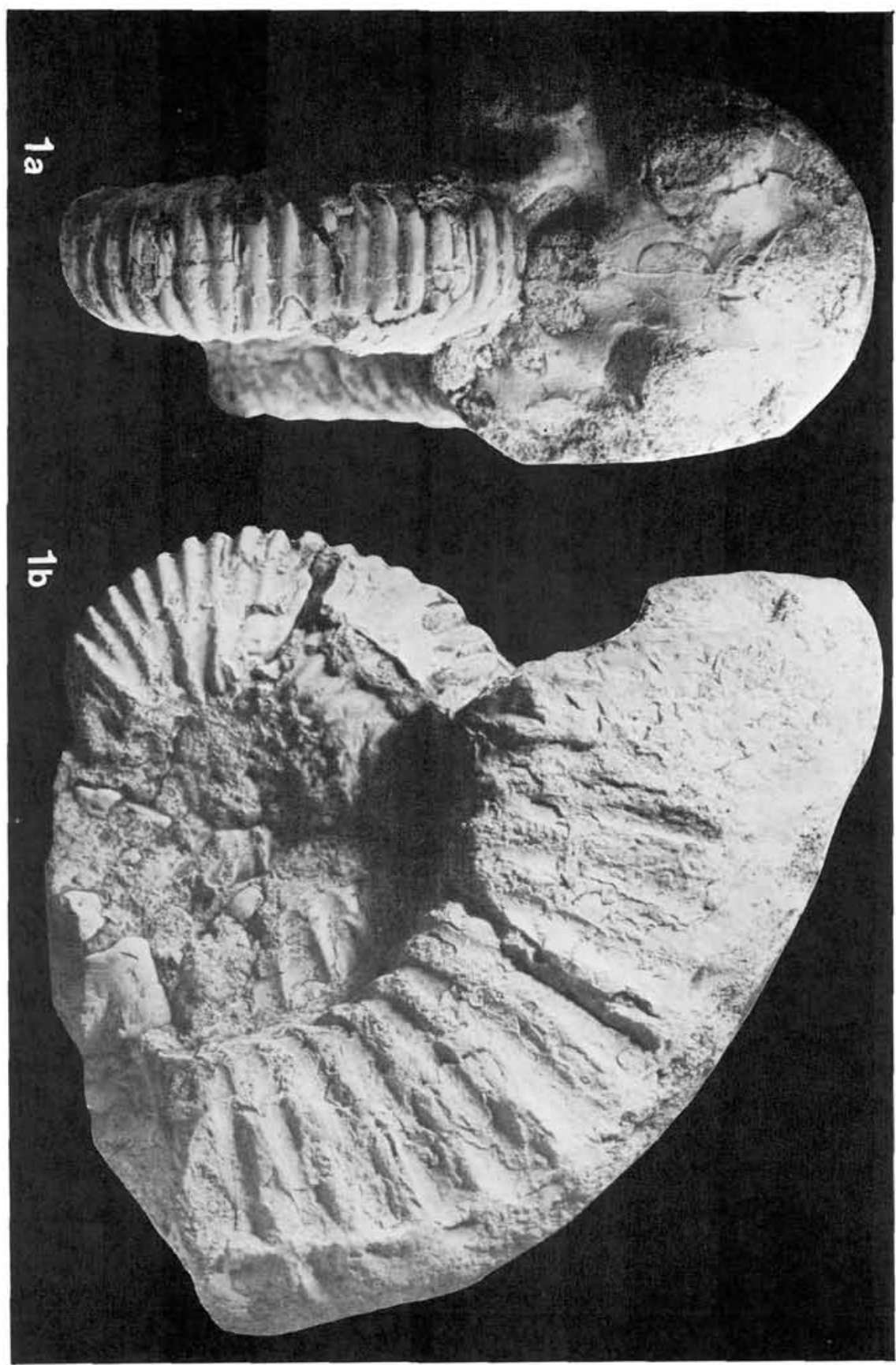

PLATE 1

Fig. 1. Hypacanthoplites milletioides Casey. MMH 2025. Slightly reduced (see also fig. 4). 

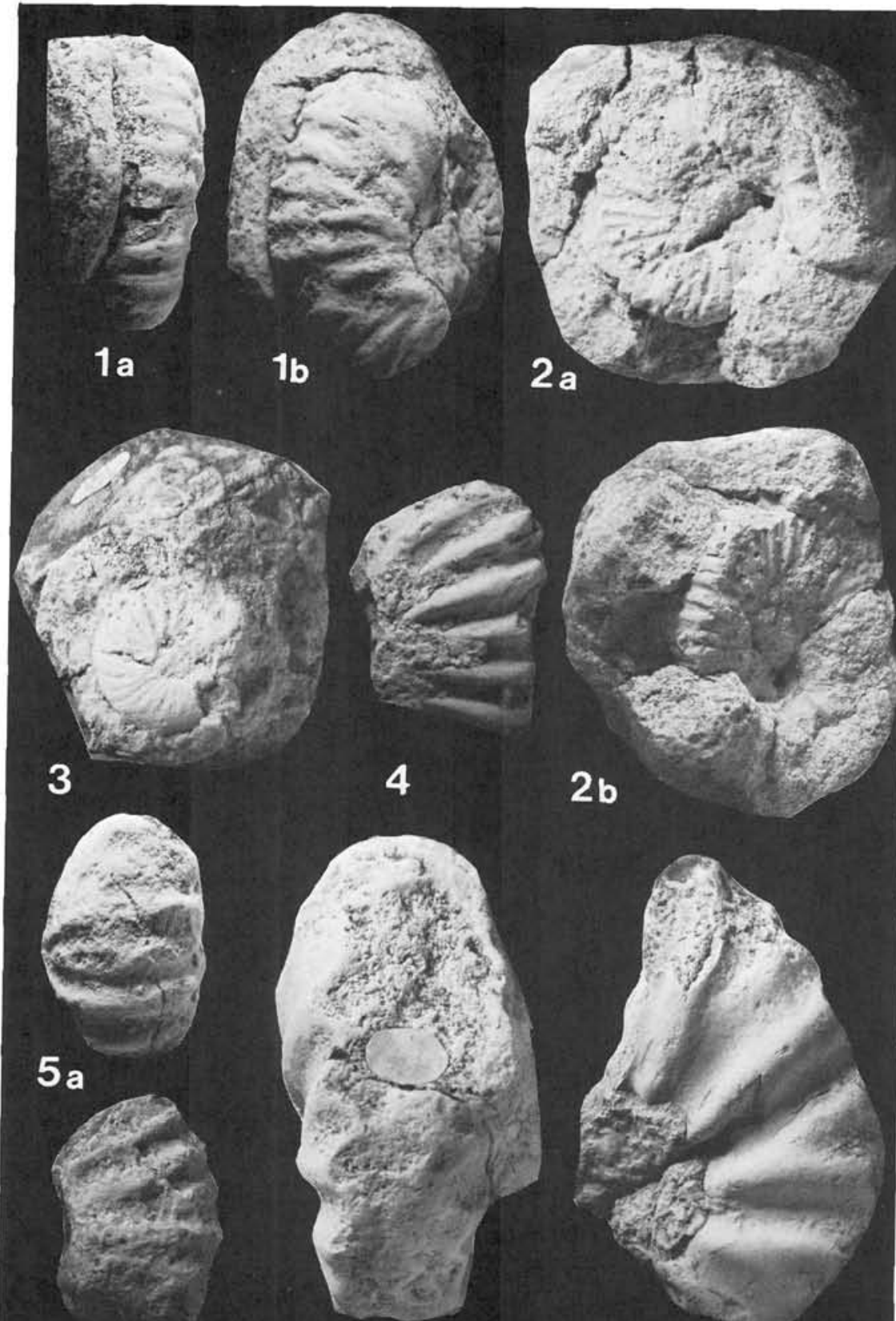

$5 b$
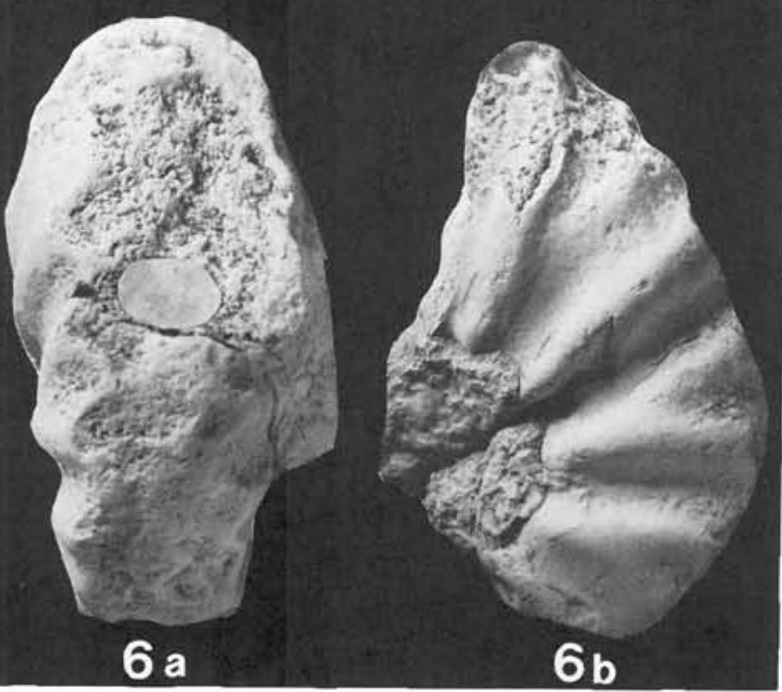

PLATE 2

Figs. 1, 2, 4, 5. Hypacanthoplites, species undetermined. 1 is MGUH $15128 ; 2$ is MGUH $15129 ; 4$ is MGUH 15130; 5 is MGUH 15131. Fig. 3. Epileymeriella (Epileymeriella) cf. hitzeli Jacob? MGUH 15180. Fig. 6. Protohoplites (Hemisonneratia) cf. puzosianus (d'Orbigny). MGUH 15132. 


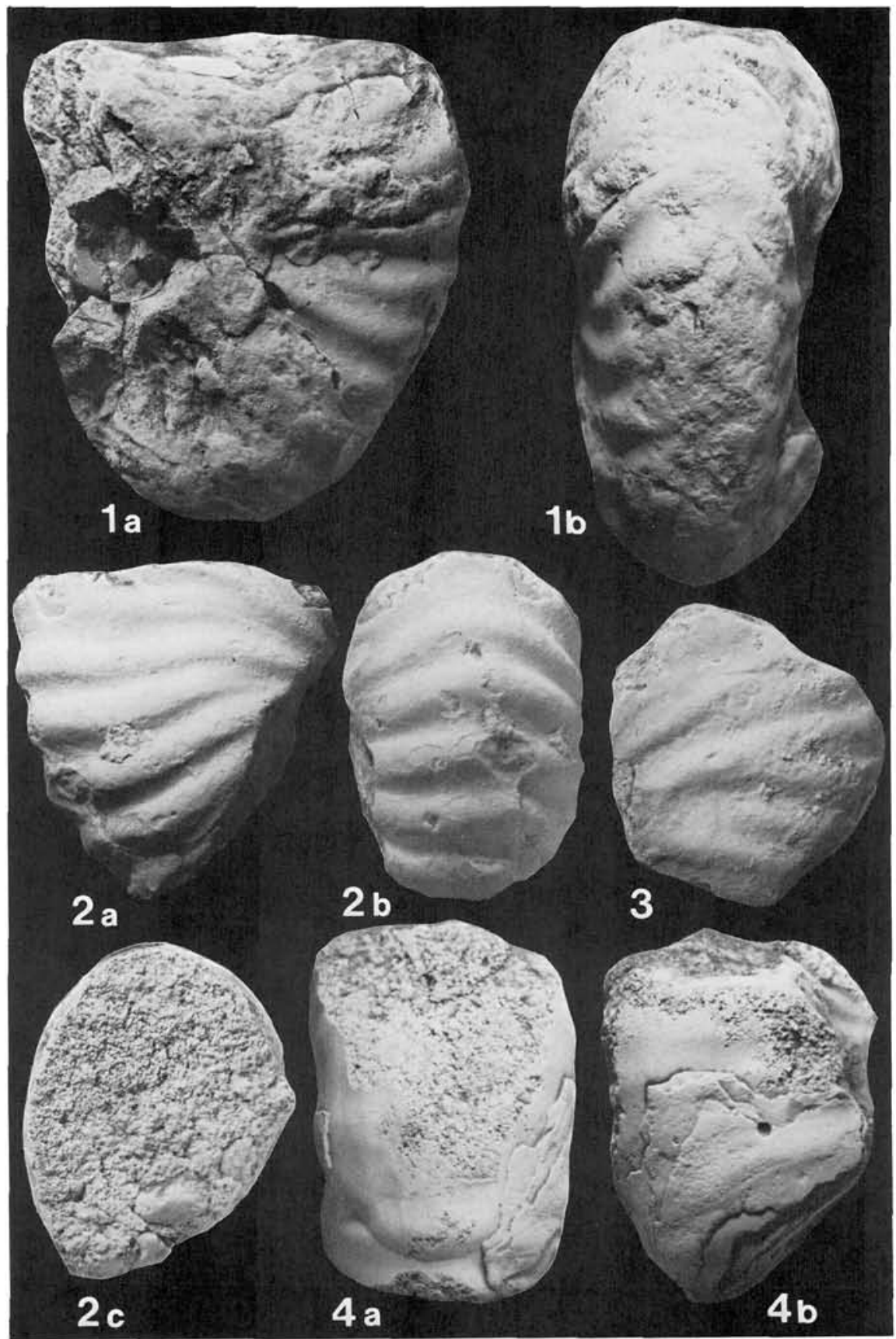

PLATE 3

Fig. 1. Pseudosonneratia sp. MGUH 15147. Fig. 2. Sonneratia kitchini Spath. MGUH 15135. Fig. 3. Sonneratia species undetermined. MGUH 15141 (see also pl. 5, fig. 2). Fig. 4. Sonneratia? sp. MGUH 15143 (see also pl. 4 , fig. 3 ). 


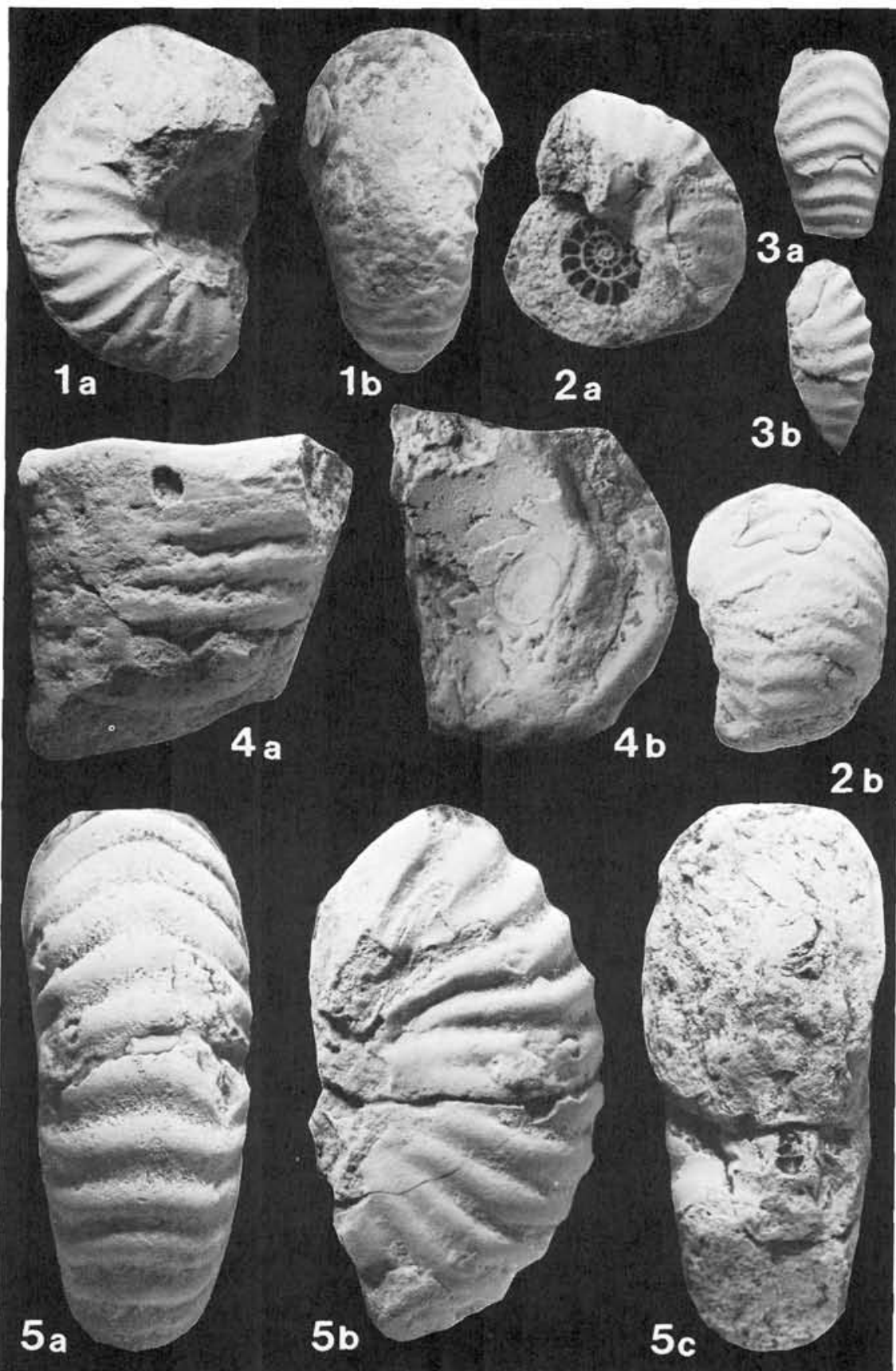

PLATE 4

Figs. 1, 5. Sonneratia kitchini Spath. 1 is MGUH 15136: 5 is MMH 2021. Fig. 2. Sonneratia perinflata Breistroffer. MGUH 15140 (see also fig. 5). Fig. 3. Sonneratia? sp. MGUH 15143 (see also pl. 3, fig. 4). Fig. 4. Belemnite phragmocone, labelled Hamites elegans. MGUH 15184. 


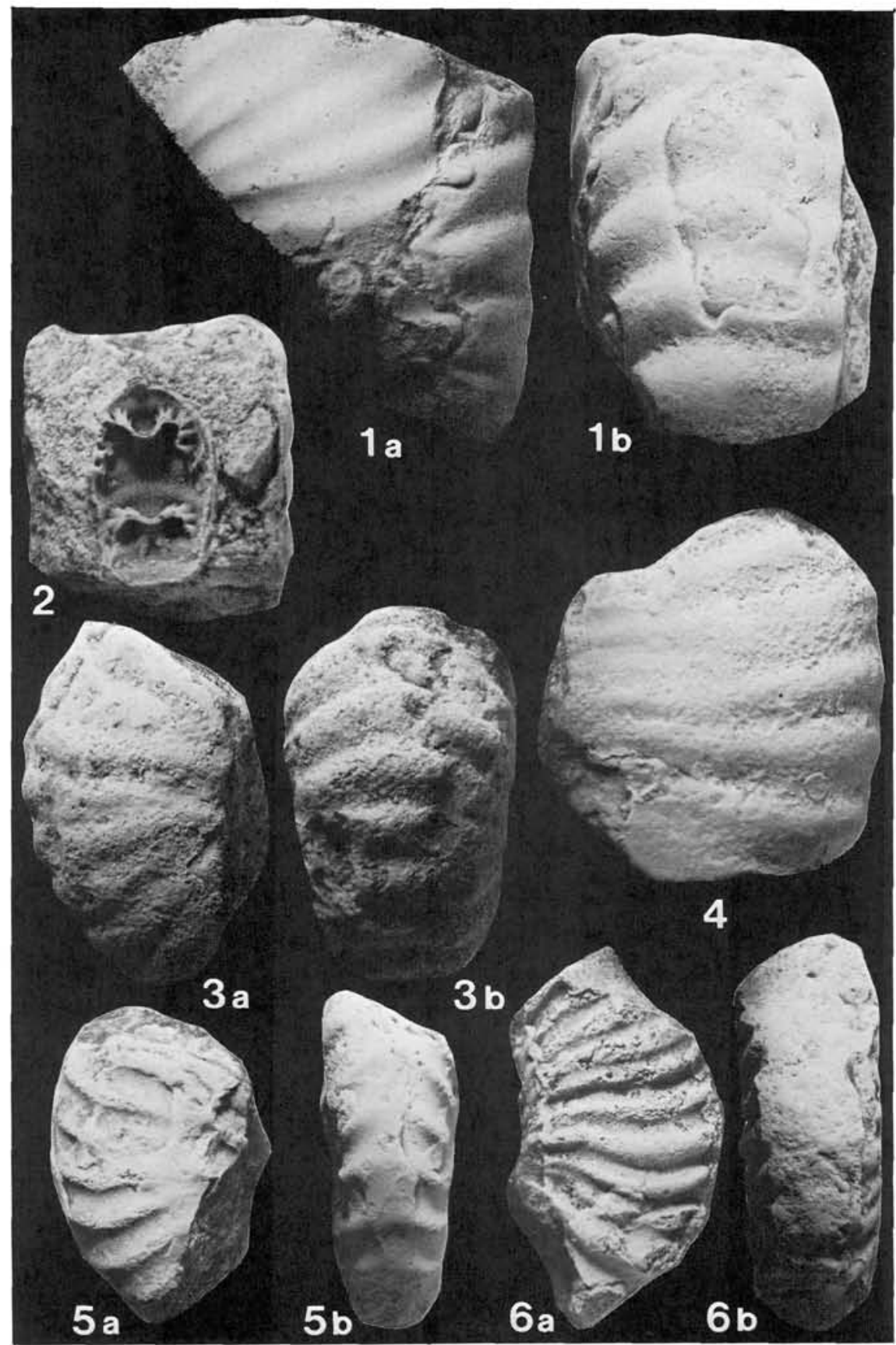

PLATE 5

Figs. 1, 4. Sonneratia kitchini Spath. 1 is MGUH 15137; 4 is MGUH 15138. Fig. 2. Sonneratia sp. MGUH 15141 (see also pl. 3, fig. 3). Fig. 3. Sonneratia cf. rotator Casey. MGUH 15139. Fig. 5. Pseudosonneratia sp. MGUH 15147. Fig. 6. Leymeriella sp. MGUH 15178. 


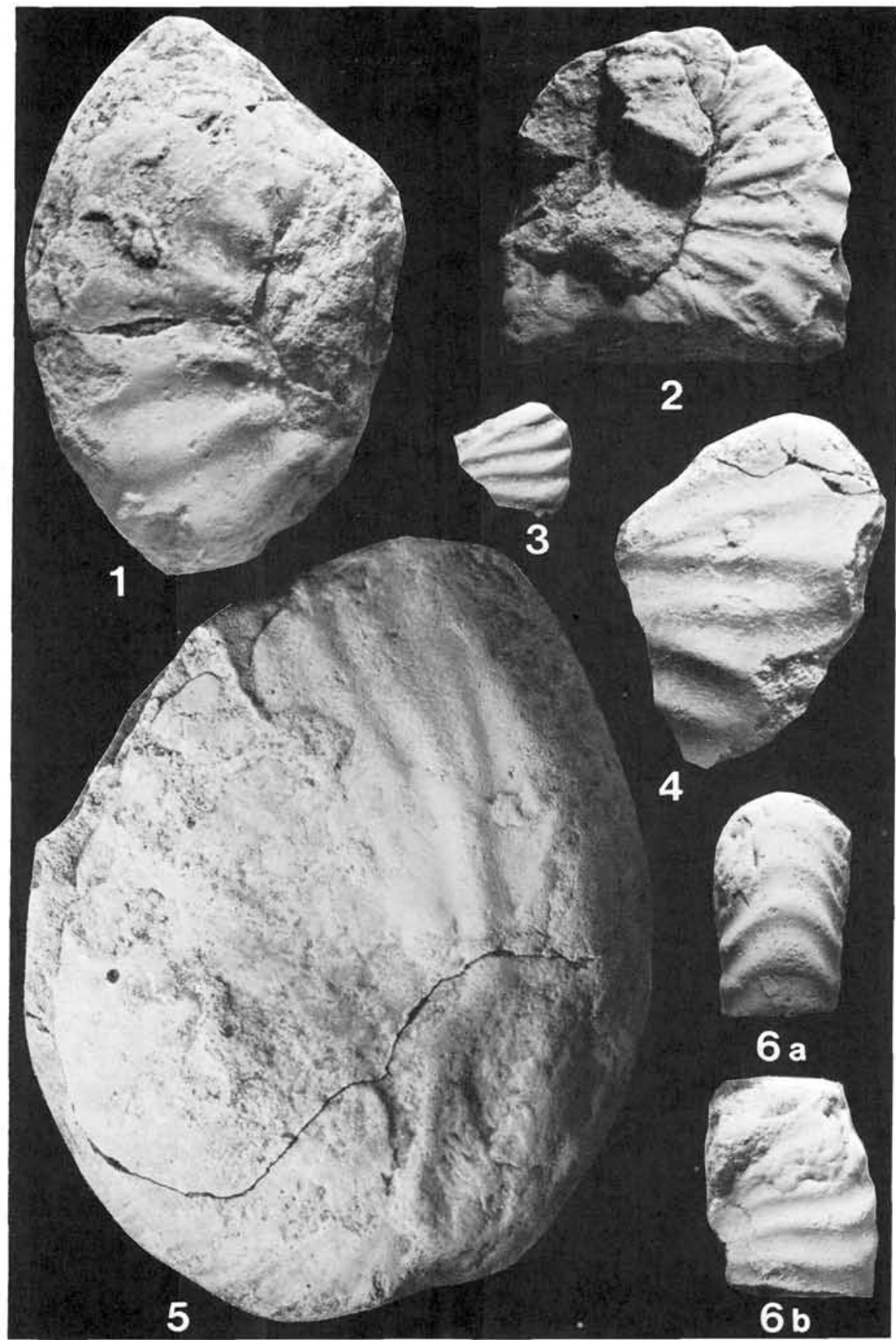

PLATE 6

Fig. 1. Otohoplites guersanti (d'Orbigny). MGUH 15134. Fig. 2. Pseudosonneratia occidentalis pluricostata Casey? MGUH 15151. Figs. 3, 6. Pseudosonneratia sp. 3 is MGUH 15148; 6 is MGUH 15149. Fig. 4. Otohoplites sp. group of auritiformis Spath. MGUH 15133. Fig. 5. Cleoniceras? sp. MGUH 15158. 


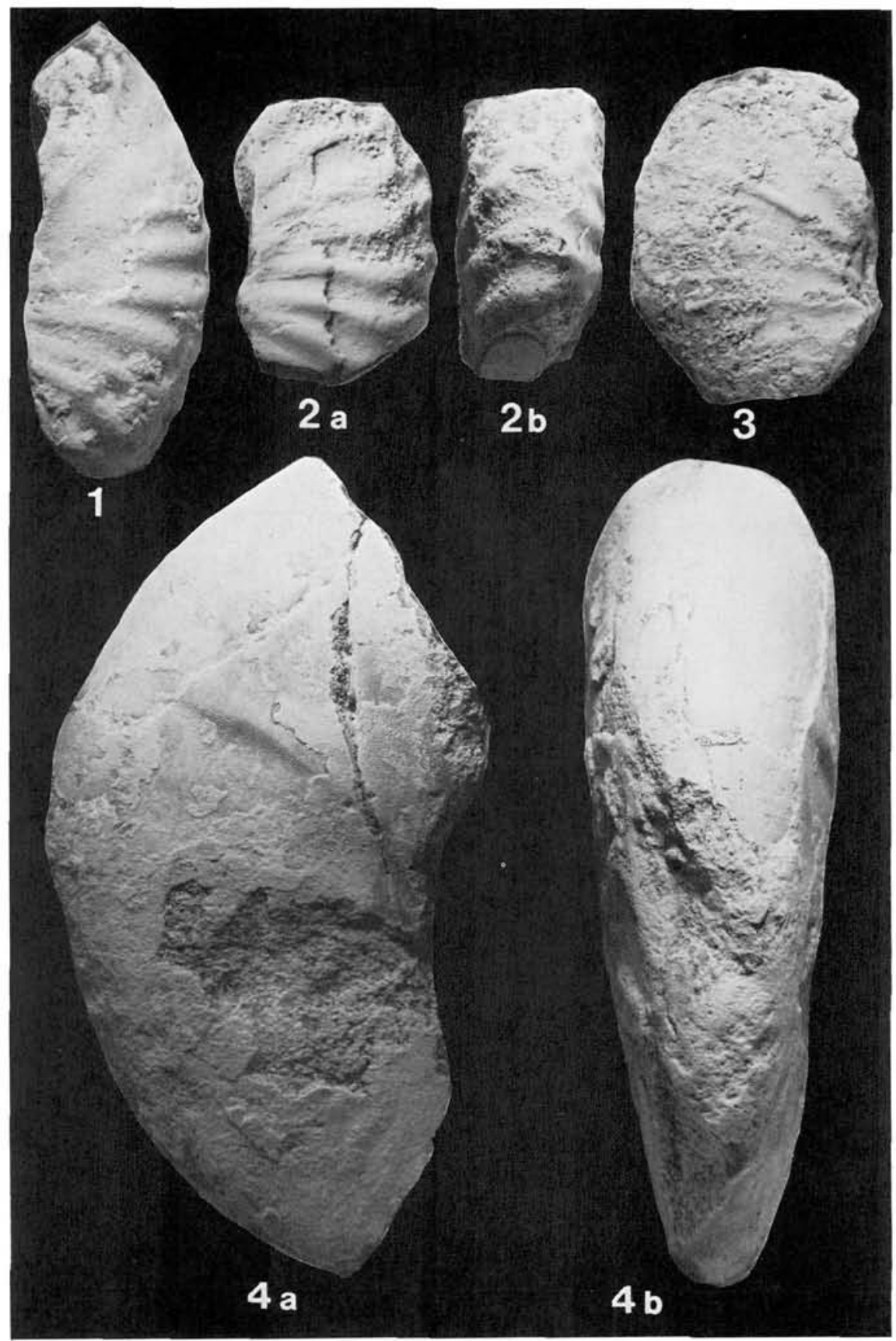

PLATE 7

Fig. 1. Sonneratia sp. MGUH 15142. Fig. 2. Pseudosonneratia sp. MGUH 15150. Fig. 3. Anadesmoceras costatum Casey. MGUH 15159. Fig. 4. Anadesmoceras cf. strangulatum Casey. MGUH 15160. 

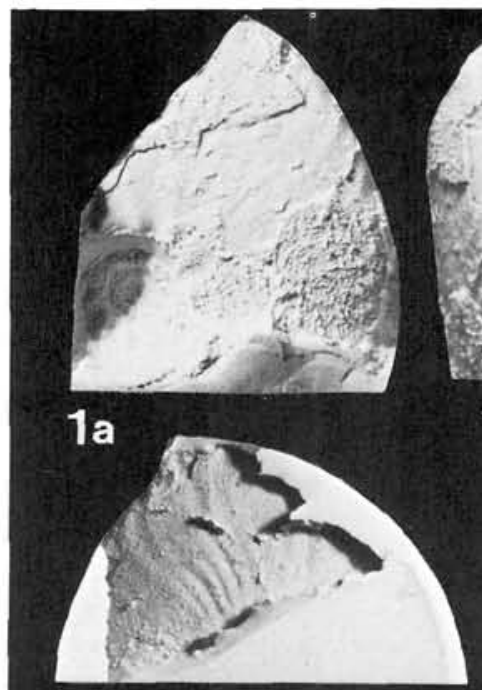

$1 \mathrm{c}$

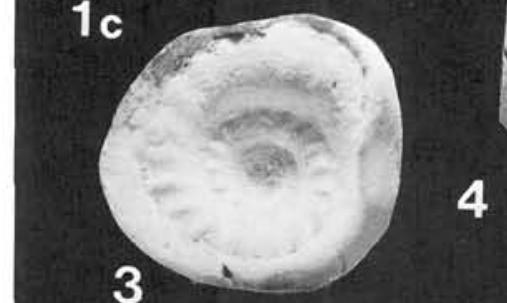

4

1b

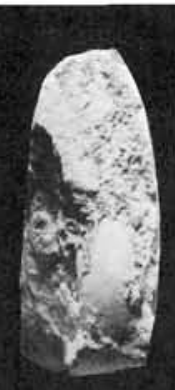

$2 a$

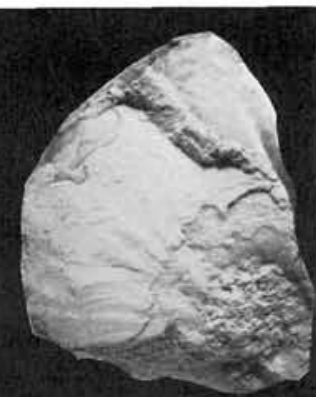

2b
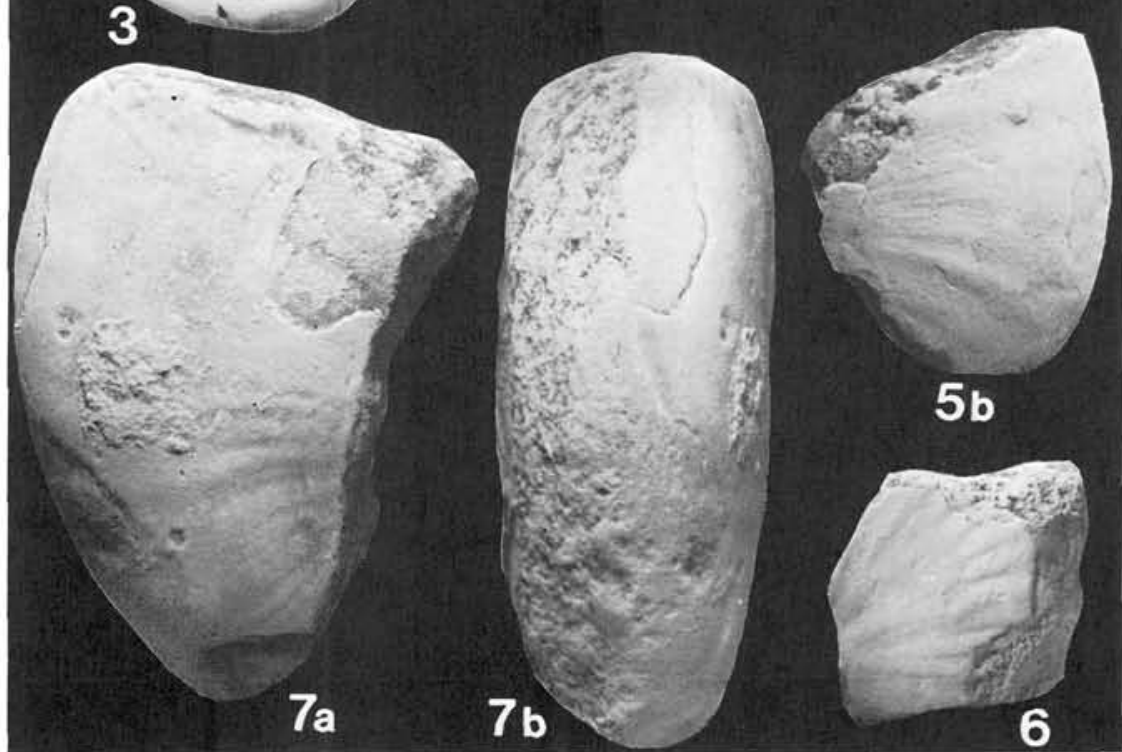

$7 a$
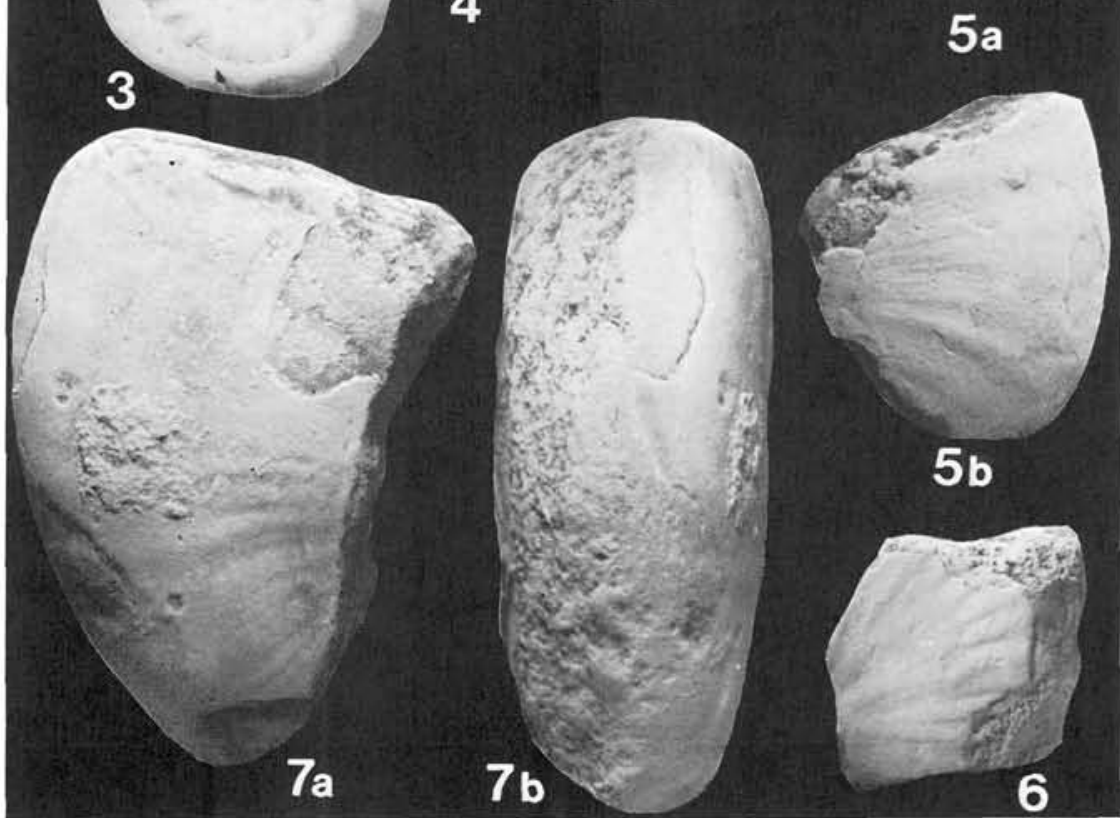

PLATE 8

Fig. 1. Anadesmoceras costatum Casey. MMH 2020. Fig. 2. Anadesmoceras group of subbaylei Spath. MGUH 15161. Figs. 3, 4. Sonneratia sp. umbilical moulds. 3 is MGUH $15144 ; 4$ is MGUH 15145. Figs. 5, 6, 7. Cleoniceras species undetermined. 5 is MGUH 15152. 6 is MGUH 15153; 7 is MGUH 15154 (see also pl. 15, fig. 3). 


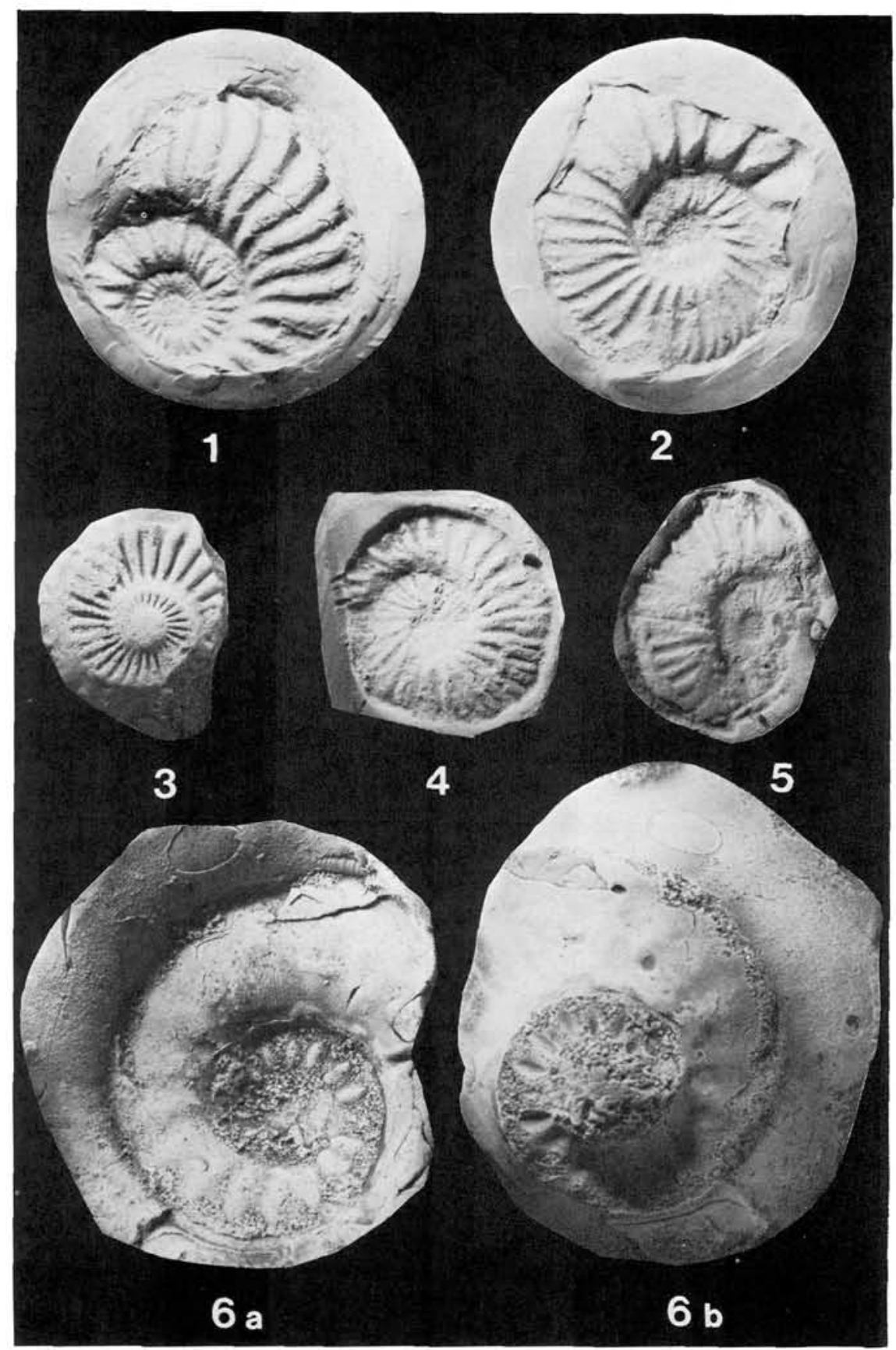

PLATE 9

Fig. 1. Leymeriella (Neoleymeriella) regularis (d'Orbigny). MMH 2017. Figs. 2, 4, 5. Epileymeriella (Epileymeriella) hitzeli (Jacob). 2 is MMH 2024; 4 is MGUH 15181; 5 is MGUH 15182. Fig. 3. Leymeriella sp. MGUH 15179. Fig. 6. Sonneratia umbilical mould. MMH 2027. 


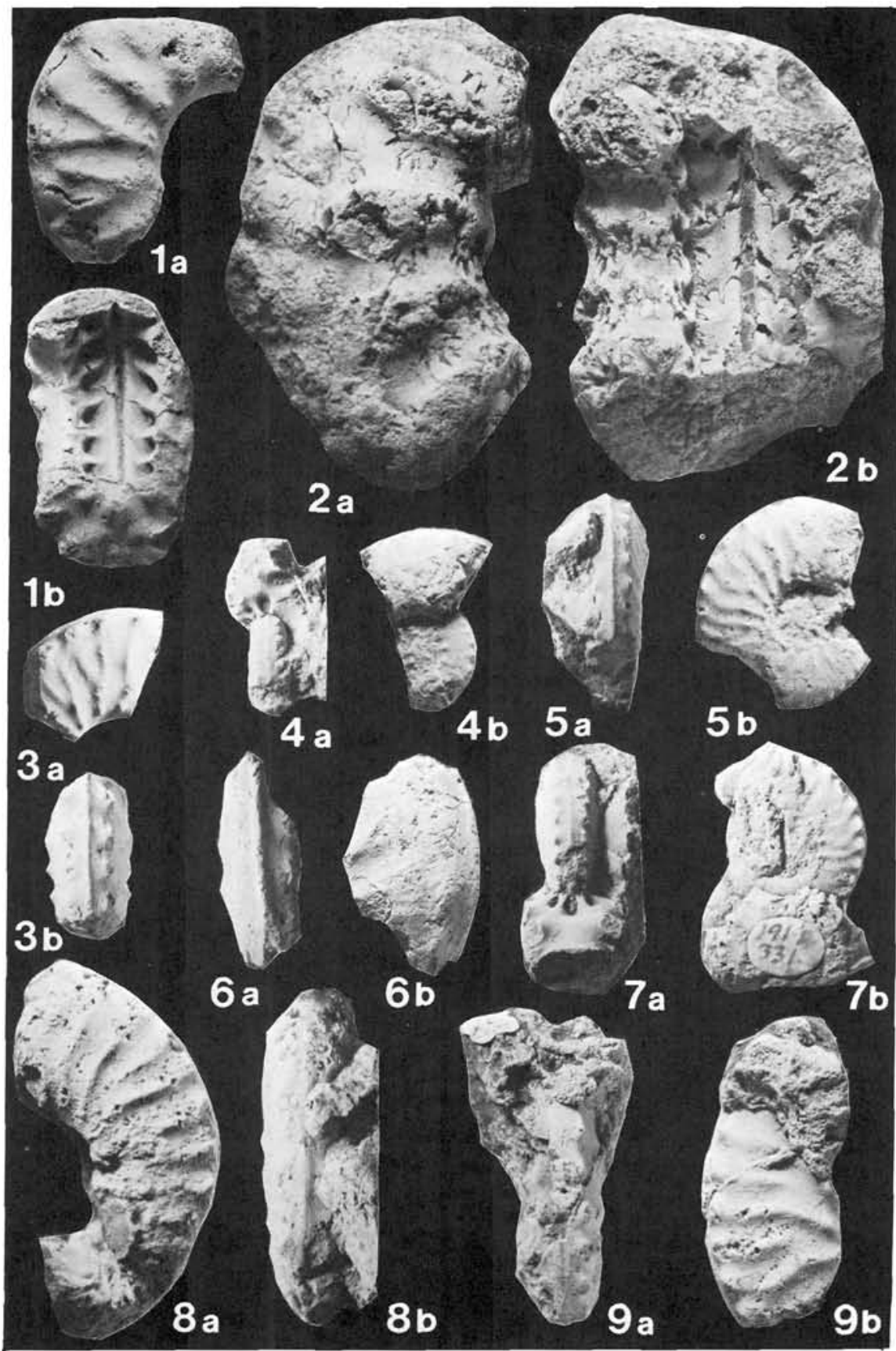

PLATE 10

Fig. 1. Schloenbachia aff. varians subtuberculata (Sharpe). MGUH 15163. Fig. 2. Schloenbachia varians varians (J. Sowerby). MGUH 15162, Figs. 3, 5, 9. Schloenbachia varians subvarians Spath. 3 is MGUH $15165 ; 5$ is MGUH 15166; 9 is MGUH 15167. Figs 4, 6, 7, 8. Schloenbachia sp. cf. varians (J. Sowerby). 4 is MGUH $15168 ; 6$ is MGUH $15169 ; 7$ is MGUH $15170 ; 8$ is MGUH 15171. 


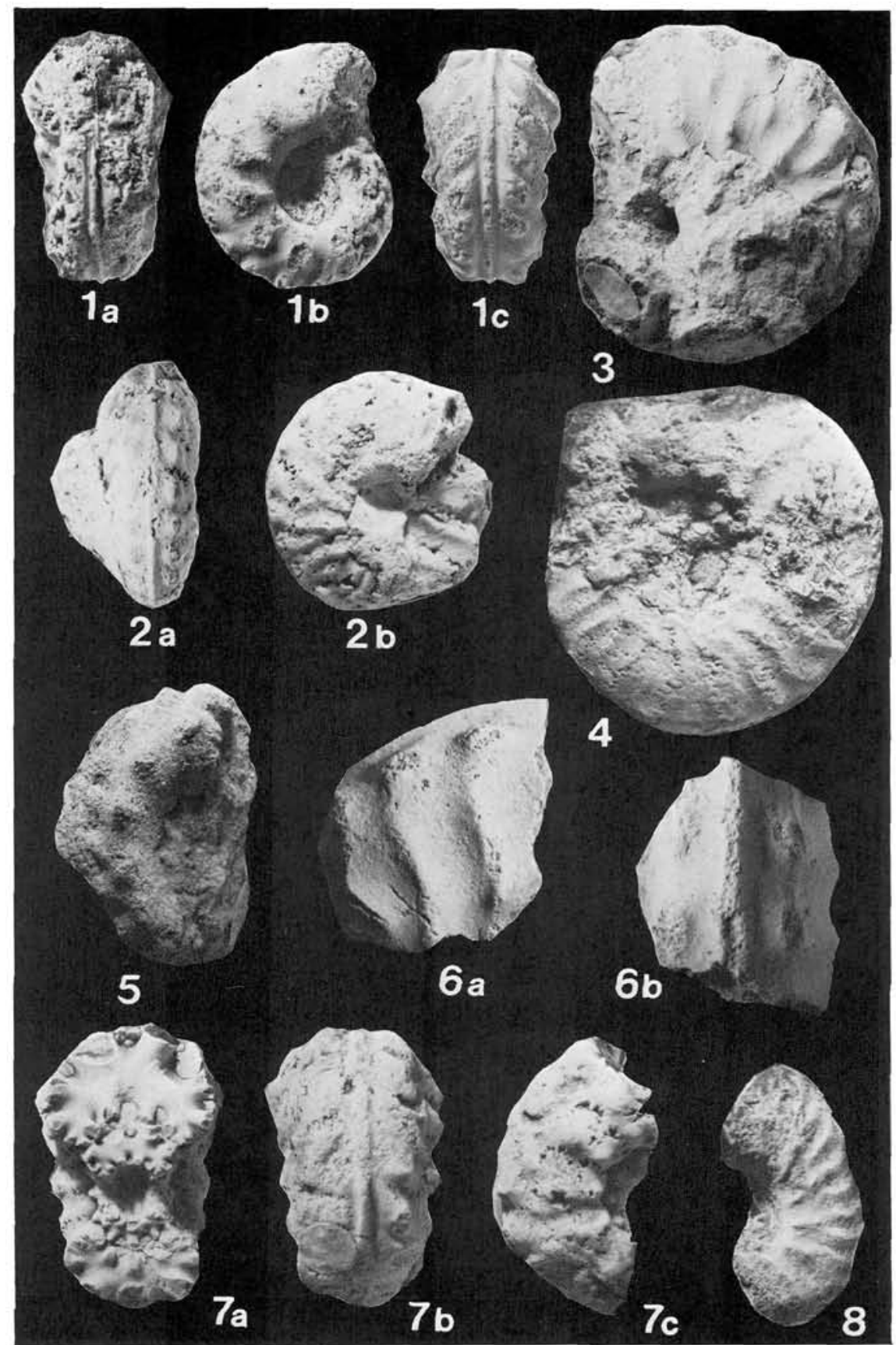

PLATE 11

Fig. 1. Schloenbachia varians varians (J. Sowerby). MMH 2019. Figs. 2, 3. Schloenbachia sp. cf. varians (J. Sowerby). 2 is MGUH 15172; 3 is MGUH 15173. Fig. 4. Schloenbachia varians subvarians Spath. MMH 2026. Figs. 5, 8. Schloenbachia cf. coupei (Brongniart). 5 is MGUH 15176; 8 is MMH 1540. Fig. 6. Schloenbachia sp. MGUH 15177. Fig. 7. Schloenbachia aff. varians varians (J. Sowerby). MGUH 15164. 


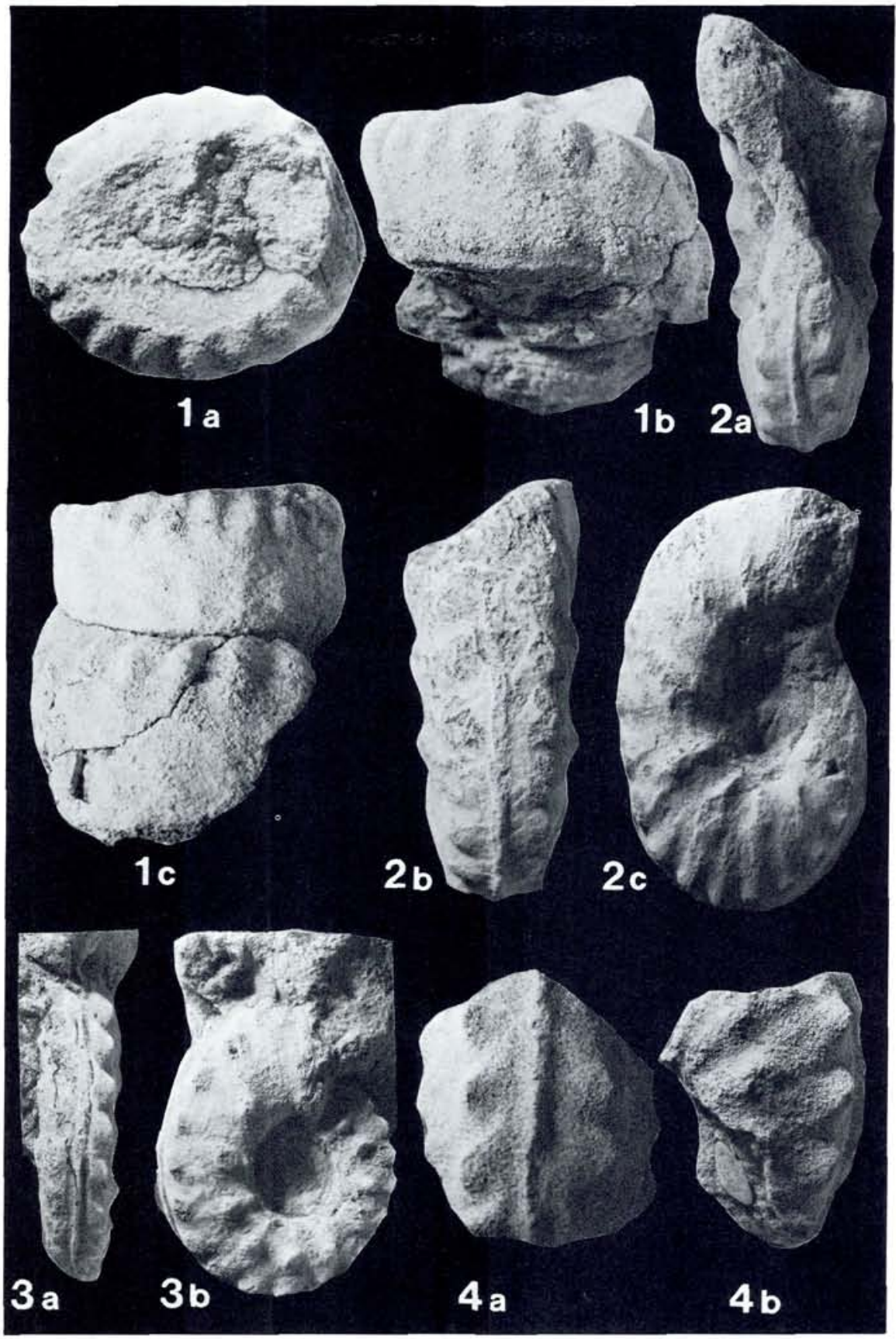

PLATE 12

Fig. 1. Turrilites scheuchzerianus BOSC. MGUH 15127. Fig. 2. Schloenbachia coupei var. nov. A. MGUH 15174. Fig. 3. Schloenbachia sp. cf. coupei (Brongniart). MMH 1539. Fig. 4. Schloenbachia coupei var. nov. B. MGUH 15175 . 


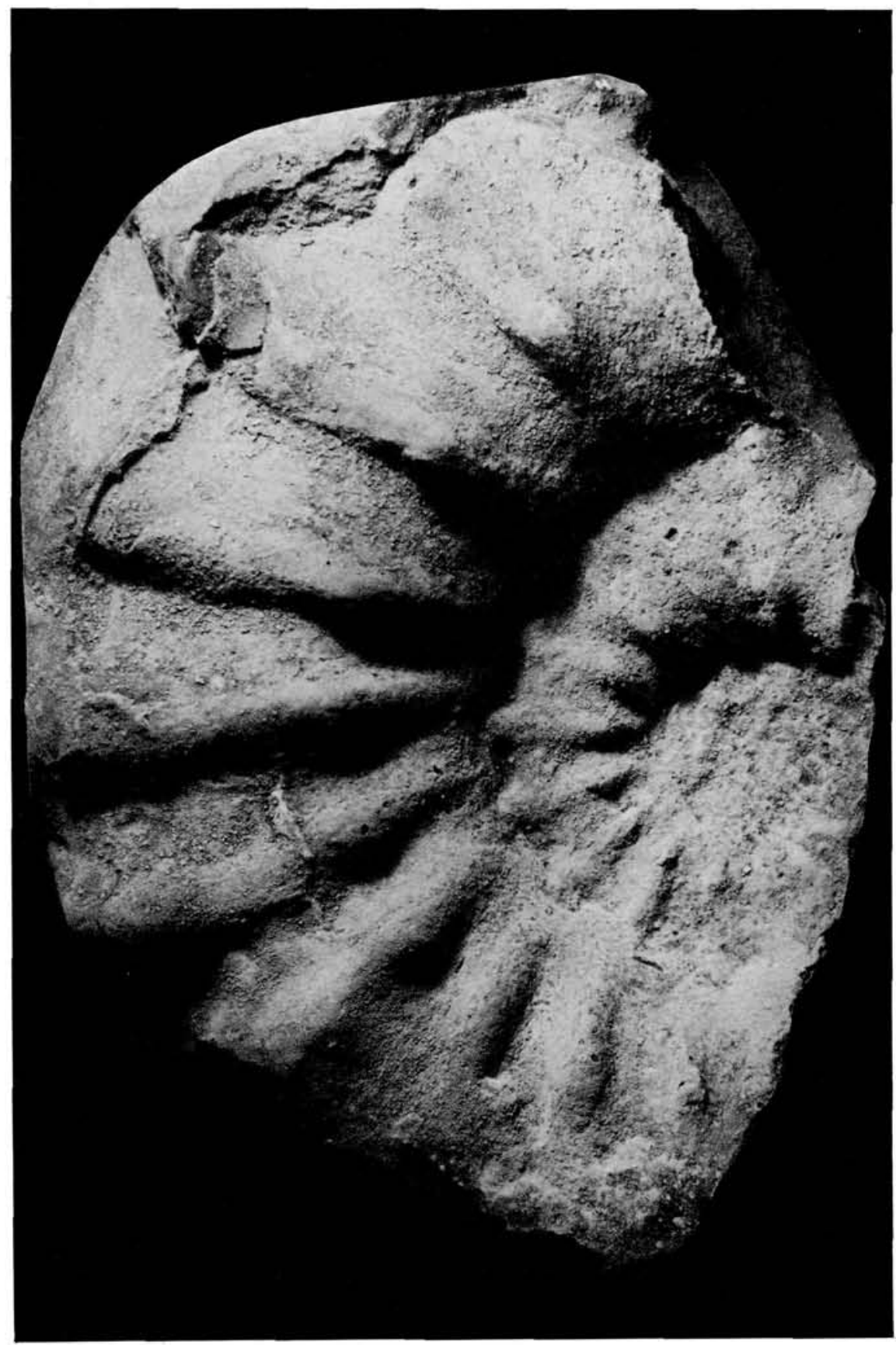

PLATE 13

Acanthoceras rhotomagense (Brongniart) sussexiense (Mantell). MGUH 15183. 


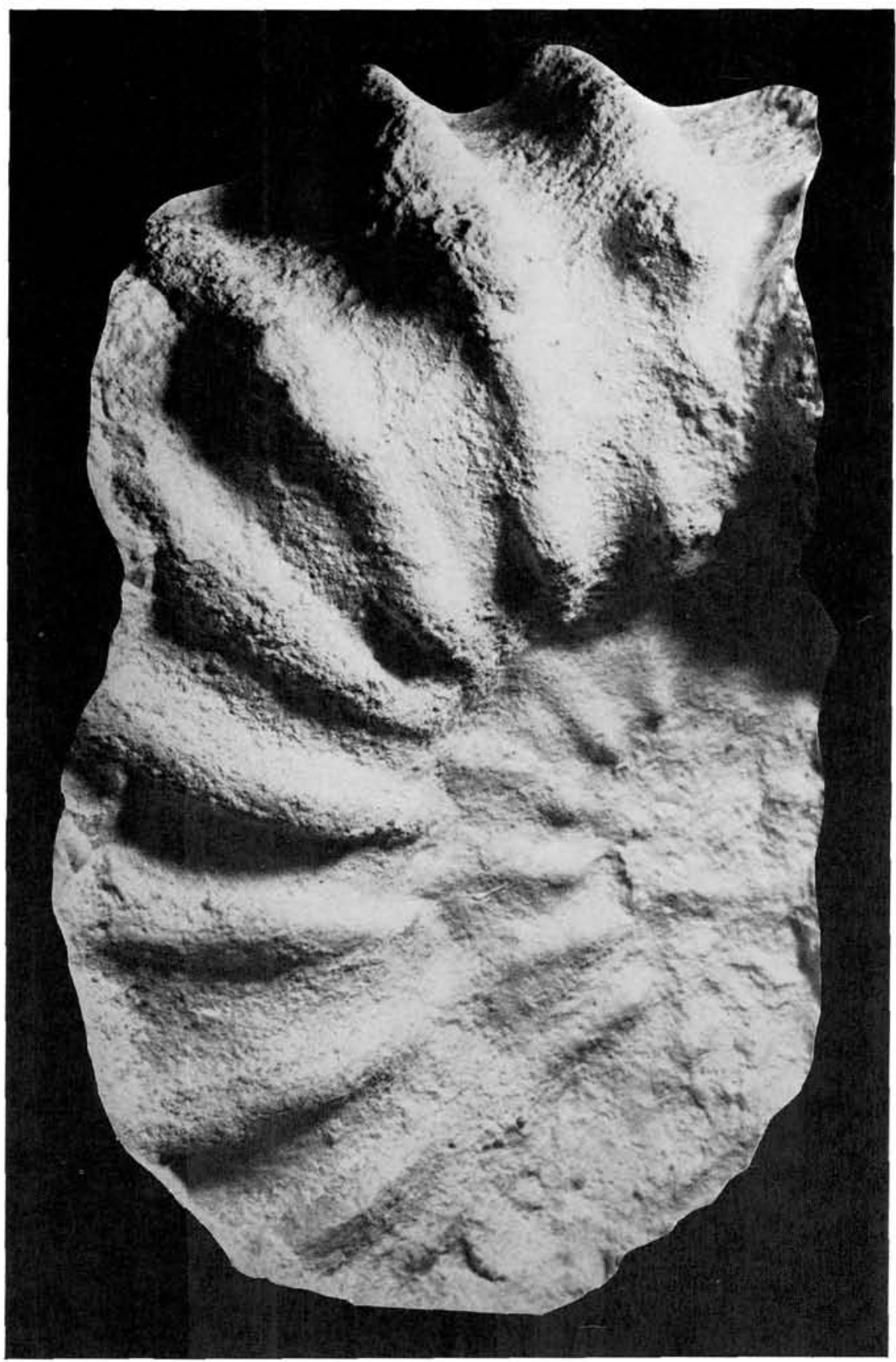

PLATE 14

Acanthoceras rhotomagense (Brongniart) sussexiense (Mantell). Reduced $\times 0.7$. MMH 5163 , 


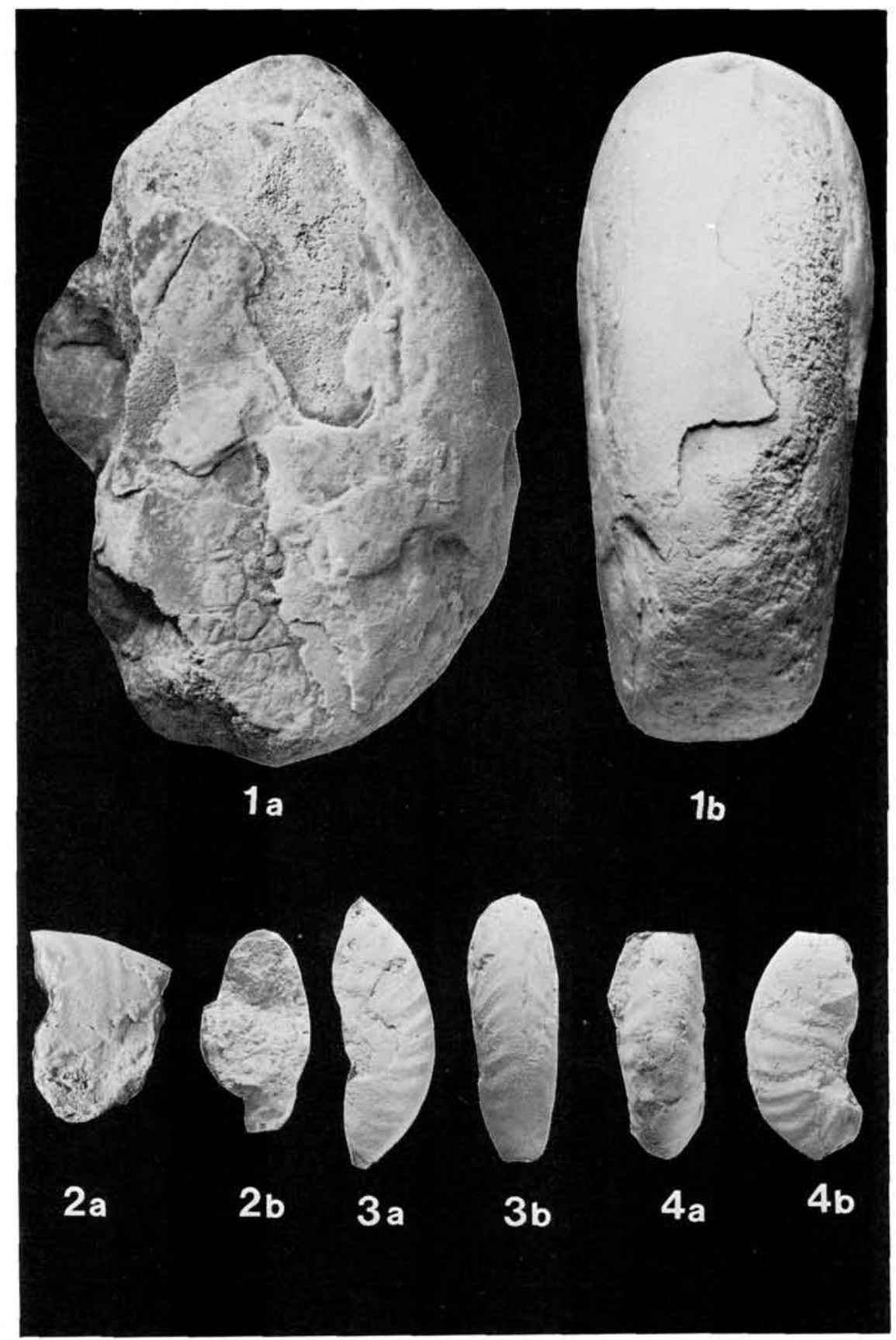

PLATE 15

Figs. $1-4$. Cleoniceras species undetermined. 1 is MGUH $15155 ; 2$ is MGUH $15156 ; 3$ is MGUH 15154 (see also pl. 8, fig. 7); 4 is MGUH 15157. 
where ribs are interrupted at mid flank - and those with continuous ribs. D'Orbigny (1842) regarded them as two separate species named $T$ : desnoyersi d'Orbigny and $T$. scheuchzerianus respectively, whilst Sharpe (1857) considered desnoyersi to be a reconstruction in which the interrupted ribbing of juveniles has been unjustifiably extended to the mature stage. Sornay (1956) re-described d'Orbigny's types, and supported Sharpe's view, whilst Collignon (1964) has figured material with interrupted desnoyersitype ribbing during middle growth which led him to support it as a separate species. Our own specimen is of the desnoyersi type, but we do not believe that specific separation can be justified.

Distribution: This species first appears at the top of the Lower Cenomanian in north west Europe and ranges into the lower part of the Upper Cenomanian, with a Middle Cenomanian acme. The geographic distribution extends from Bornholm to England, northern France to Provence, Spain, Germany, Switzerland, Italy, the Middle East, Morocco, Algeria and Tunisia, Nigeria, Zululand, Madagascar, Japan, Mexico, Texas, California and the U.S. Western Interior region of the United States.

Douvilleicerataceae Parona \& Bonarelli, 1897

Parahoplitidae Spath, 1922

Hypacanthoplites Spath, 1923

Type species: Acanthoceras milletianum (d'Orbigny) var. plesiotypica Fritel, by original designation.

Remarks: Casey (1965) has presented a full diagnosis and discussion of Hypacanthoplites, and described more than a score of species from the English Lower Greensand. Species of the genus are narrowly conceived, and the co-occurrence of a number of forms suggests that there has been oversplitting: the material available for present study is inadequate for full review of this problem, and in consequence we adopt Casey's species limits for the purposes of placing the Bornholm fragments.

Distribution: Hypacanthoplites ranges from the Upper Aptian Hypacanthoplites jacobi Zone to the Lower Albian Douvilleiceras mammilatum
Zone, with an acme in the upper part of the jacobi Zone and lower part of the tardefurcate Zone. The geographic distribution extends across Europe from Bornholm south to England and France, with important occurrences in Germany and beyond, in Transcapasia. There are also several extra-European records, as in North Africa, Iran, Texas, California and Madagascar.

Hypacanthoplites milletioides Casey, 1965.

PI. 1, figs. 1a-b; fig. 4

\section{Parahoplites milletianus (d'Orbigny) -} Ravn: p. 46, pl. 4, figs. 4a-b.

1965 Hypacanthoplites milletioides Casey: p. 432, pl. 71 , figs. $2 a-b, 3$; pl. 72 , figs. $2 a-b$; pl. 73, fig. 6; pl. 74, fig. 1; text-fig. 159 (with synonymy).

Material: MMH 2025, from the phosphatic conglomerate of the Arnager Greensand, Madsegrav, Bornholm.

Description: Ravn's figured specimen (pl. 1, figs. $1 \mathrm{a}-\mathrm{b})$ is the best-preserved Hypacanthoplites (and indeed the best preserved ammonite) from the phosphatic conglomerate at Madsegrav. It consists of a wholly septate nucleus approximately $78 \mathrm{~mm}$ in diameter, and a badly abraded septate outer whorl with an estimated maximum whorl height of $55 \mathrm{~mm}$. Coiling is moderately evolute, $46 \%$ of the previous whorl being covered on the inner whorls, becoming more evolute at maturity. The relative proportions cannot be fully determined, but the umbilicus comprises about $34 \%$ of the diameter of the inner whorls, and is quite deep, with a subvertical, flat wall. The umbilical shoulder is abruptly rounded, and the whorls as wide, or a little wider than high, with gently swollen inner flanks and flattened, convergent outer flanks, somewhat abruptly rounded ventrolateral shoulders and a flattened venter. The greatest breadth is low on the flank, at, or just outside the umbilical bulla. There are an estimated forty-five ribs on the nucleus preserved, and approximately half this number arise at the umbilical seam, and are well developed across the umbilical wall, strengthening into prominent bullae low on the flank at the smallest diameter visible. These bullae give rise to pairs of ribs, which are crowded, narrow, straight and prorsiradiate. All ribs pass uninterrupted across 


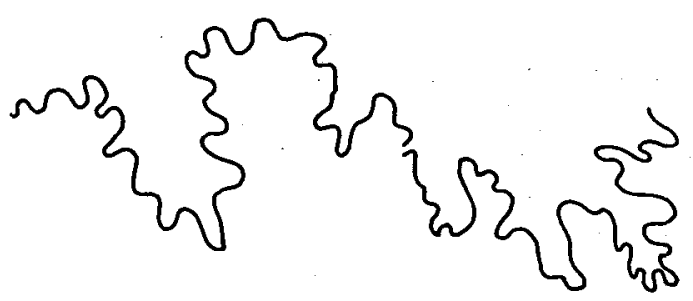

Fig. 4. Hypacanthoplites milletioides Casey, 1965. Partial suture of MMH 2025, $\times$ ca. 4.5 (see also pl. 1, fig. 1).

the venter, where they are strengthened so as to become as wide or wider than the interspaces, and distinctively flat-topped (pl. 1, fig. 1b) and rounded.

As size increases, the umbilical bullae decline markedly. No distinct ventral tubercles are present, but at the smallest diameter visible, the distinctness of the ventrolateral angulation suggests their presence on the juvenile.

On the outer whorl, bullae are lost, and on the lower flank (all that is preserved), the ribs are straight and even, without sign of either branching or intercalation.

Suture line simple, with little incised elements (fig. 4).

Remarks: The specimen described has a nucleus which is very similar to the specimen from Grandpré (Ardennes) figured by Casey (1965, text-fig. 159) which is of similar dimensions. The outer whorl compares well with the crushed holotype (Casey 1965, pl. 74, fig. 1) in so far as it preserves only the inner flank below the point of rib bifurcation/intercalation.

$H$. milletioides is characterized by ribbing style, especially the tendency for long secondary ribs to branch from the umbilical bulla, and early loss of ventral tubercles. These features separate it from H. subelegans Breistoffe (= Ammonites milletianus Pictet \& Campiche, 1860, pl. 37, figs. 5a-b). H. milletianus d'Orbigny (lectotype refigured by Casey 1965, text-fig. 160) is more coarsely ribbed and tuberculate; the same is true of species such as $H$. jacobi (Collet) (lectotype refigured by Casey 1965 , text-fig. 156a-b) which also has a different rib pattern, with shorter intercalatories, as does $H$. anglicus Casey, especially the var. audax. Other species differ in more flexuous ribbing (e.g. $H$. sigmoidalis Casey) or are densely and finely costate $(H$. rubricosus Casey, H. elegans (Fritel), H. subrectangularis (Sinzow)). These and other species are discussed by Casey (1965: 421-455).

Distribution: Hypacanthoplites milletioides is known from the Farnhamia farnhamensis to Hypacanthoplites milletioides Subzones of the English Leymeriella tardefurcata Zone, and has also been recorded from the Northern Caucasus.

Hypacanthoplites spp. undetermined.

Pl. 2, figs. 1a-b, 2a-b, 4, 5a-b.

Material: MGUH 15128-15131, MM 1919.331.28 and 1919.331.30 from the phosphatic conglomerate of the Arnager Greensand at Madsegrav, Bornholm.

Description: The material before us comprises a series of battered fragments (pl. 2, figs. 1a-b, 4, 5a-b), referred to Hypacanthoplites with varying degrees of confidence on the basis of the presence of one or several of the following features:

(a) presence of umbilical bullae giving rise to pairs of ribs,

(b) strength, height and roundness of ribbing,

(c) presence of ventral tubercles,

(d) a flattened venter on which ribs strengthen,

(e) lack of lateral tubercles.

With such poor material, specific comparisons are most difficult. The best preserved sample (pl. 2, figs. 2a-b), with fine dense ribbing, flat sides, angular shoulders and a flat venter, together with intercalated ribs which arise well out from the umbilicus represents one extreme. The other is represented by robustly ornamented fragments such as those shown in pl. 2, figs. 1a-b, $5,5 a-b$. These specimens could belong to any of several species, but are so poor that fuller comparisons would be fruitless.

Occurrence: These fragments can be taken as no more than a generic record, thus indicating no more precise an horizon than the late Aptian jacobi Zone to early tardefurcata - low mammilatum Zones; the relatively common occurrence of the genus suggests highest jacobi or low tardefurcata Zone. 
Ammonitina Hyatt, 1889

Hoplitaceae Douvillé, 1890

Hoplitidae Douvillé, 1890

Hoplitinae Douvillé, 1890

Protohoplites Spath, 1923

Type species: Ammonites archiacianus d'Orbigny, by monotypy. Subgenus Hemisonneratia Casey, 1952

Type species: Ammonites puzosianus d'Orbigny, by original designation.

- Remarks: Casey (1952: 135) introduced Hemisonneratia for hoplitids which form a gradational series from Sonneratia to Protohoplites sensu stricto. Unlike Protohoplites, the ribs are not interrupted over the venter.

Distribution: Hemisonneratia characterizes the Protohoplites (Hemisonneratia) puzosianus Subzone at the top of the Douvilleiceras mammilatum Zone. Its geographical range extends from Bornholm south to southern England, across France (Machéroménil), to Transcaspasia.

Protohoplites (Hemisonneratia) cf. puzosianus (d'Orbigny, 1841)

Pl. 2, figs. $6 a-b$.

Synonymy: Casey (1965: 486-487) has recently given a complete synonymy for this species.

Material: One specimen, MGUH 15132, from the phosphatic conglomerate of the Arnager Greensand at Madsegrav, Bornholm.

Description: The specimen consists of a battered fragment of a body chamber with a maximum whorl height of $30 \mathrm{~mm}$. The umbilicus appears to have been of moderate size, and quite deep. The whorl section was probably slightly depressed and hexagonal, with the lower flanks inflated, the maximum breadth being just outside the umbilical bullae, with flattened, convergent outer flanks, rounded ventrolateral shoulders and a flattened venter. Ornament consists of four strong umbilical bullae which give rise to pairs of strong slightly flexed rounded ribs.

Remarks: This poor fragment, apparently one of those recorded by Ravn (1925: 48) as Parahop- lites puzosianus, has been separated from the numerous Sonneratia in our collection because of the strong ribs arising in pairs, and the hexagonal whorl section. It most closely resembles $P$. (Hemisonneratia) puzosianus (lectotype refigured by Casey 1965 , text-fig. $184 d-e)$, although the venter is too poorly preserved to show the depression typical of Hemisonneratia.

P. (Hemisonneratia) cantianus Casey, 1965: 489, pl. 81, figs. 5a-c; pl. 82, figs. 1a-b; text-fig. 185e) is more depressed with a marked siphonal depression. $P$. (H.) gallicus Breistroffer (Casey 1965: 490, pl. 80, figs. 5, 6a-b; pl. 81, figs. 4a-b; text fig. $185 \mathrm{a}-\mathrm{d}$ ) is also much more depressed.

Distribution: $P$. (H.) puzosianus Subzone at the top of the Douvilleiceras mammilatum Zone of southern England, France, and Mangyshlak (Transcaspasia).

\section{Otohoplites Steinmann, 1925.}

Type species: Ammonites raulinianus d'Orbigny, by the subsequent designation of Casey (1952).

Remarks: Casey (1965) has given a full review of this genus, which is believed to be the rootstock from which arose the diverse Middle and Upper Albian hoplitids which in many cases homoeomorph their Lower Albian predecessors. This is particularly true of the compressed lautiform species of Otohoplites, which are difficult to separate from certain Callihoplites. Casey (1965: 493) notes that the ribbing of Callihoplites is sharper, the umbilical bullae better differentiated, more distant from the umbilical seam, and more widely spaced, so that more ribs arise from a single bulla than in Otohoplites. The siphonal region of Callihoplites is generally raised, and the suture line asymmetric in relation to the plane of coiling.

Occurrence: Otohoplites is restricted to the Hoplitinid Province of Owen (1971); it is best known from England and northern France, although extending as far east as Transcaspasia, south to Balme de Rencurel (Isère) and north to Bornholm. The stratigraphic distribution is limited to the Lower Albian Douvilleiceras mammilatum Zone, the genus especially characterizing the 
Otohoplites raulinianus and Protohoplites (Hemisonneratia) puzosianus Subzones.

Otohoplites sp. group of auritiformes (Spath, 1925)

Pl. 6, fig. 4.

Synonymy: See Casey 1965: 511 for a complete synonymy.

Material: One fragment only, MGUH 15133, from the phosphatic conglomerate of Arnager Greensand, Madsegrav, Bornholm, labelled 'Hoplites auritus', and mentioned by Ravn (1925: 45).

Description: The specimen consists of an internal mould of part of one side of a body chamber fragment. Although neither umbilical margin nor venter are preserved, the whorl height can be estimated at approximately $37 \mathrm{~mm}$.

The whorl side is almost flat, with the greatest breadth close to mid-flank, converging towards the venter. Five ribs are preserved; these are prorsiradiate, low, broad and subdued. They arise in pairs from what appear to have been feeble umbilical bullae, the front rib of one pair and the rear of the other joining at an elongate ventral clavus (only the base of which is preserved) in characteristic lautiform style.

Remarks: Although very fragmentary, the lautiform ribbing of this individual indicates hoplitid affinities. The weakness and bluntness of the ribs is like that of Otohoplites rather than later Albian forms, such as some Callihoplites species. Casey (1965) has described or discussed almost a score of species and varieties of Otohoplites from the raulinianus and puzosianus Subzones of England and northern France, several based on unique or fragmentary individuals, in many cases differentiated on details of ornament and form that are well within commonly accepted ranges of intraspecific variation, suggesting that only a few rather variable species are really represented. Amongst his named forms, the following are either too coarsely ornamented or too inflated to be confused with our specimen: $O$. raulinianus (d'Orbigny); $O$. polygonalis Casey; $O$. waltoni Casey and var. niger Casey; $O$. destombesi Casey. In $O$. simplex Casey ribbing is simple rather than lautiform, as it is in $O$. guersanti (d'Orbigny), $O$. oweni Casey and $O$. involutus Casey.

Of lautiform species, there is a marked similarity of rib style, strength and density to that of the Otohoplites elegans (Spath) (Casey 1965: 497, pl. 83, figs. 4a-b; pl. 84, figs 4a-b, 6; text-figs $192 \mathrm{~h}, \mathrm{i})-O$. auritiformis (Spath) (Casey 1965: 511, pl. 83, figs 2, 3a-b; text-figs $187 \mathrm{i}, 190 \mathrm{~d}, 191 \mathrm{c}-\mathrm{e}, 192 \mathrm{a}-\mathrm{b})$ group, especially the feebly ribbed variants of the latter. The closely ribbed $O$. glyphus Casey, 1965: 513, pl. 85, fig. 1; text-fig. 191a-b); O. subchloris Casey, 1965: 514, pl. 85, figs 3, 4a-b; pl. 86, figs 6-7; text-fig. 187e) and $O$. subguersanti Casey, 1965: 515 , text-fig. $192 \mathrm{c}-\mathrm{f}$ differ in minor details of ornament such as to suggest that these two could be regarded as conspecific, all five 'species' mentioned above perhaps being no more than morphological variants. We can no more suggest this possibility; the name auritiformis has priority.

Distribution: The Otohoplites auritiformis group is known from the Lower Albian Douvilleiceras mammilatum Zone, Otohoplites raulinianus and Protohoplites (Hemisonneratia) puzosianus Subzones of England, northern France and Transcaspasia.

Otohoplites guersanti (d'Orbigny, 1841)

PI. 6, fig. 1.

Synonymy: Casey (1965: 505-506) has recently given a complete synonymy for this species.

Material: One specimen only, MGUH 15134, from the phosphatic conglomerate of the Arnager Greensand, Madsegrav, Bornholm.

Description: The specimen is a phosphatic mould of a body chamber with a maximum whorl height of $35 \mathrm{~mm}$. One side and the venter are badly worn. The whorl section is compressed, with the greatest breadth at the umbilical bulla. The inner flanks are gently swollen and the outer flank somewhat concave, converging to the apparently subtabulate venter. There are six prominent umbilical bullae on the third of a whorl preserved. These give rise to single broad, flat low slightly flexed ribs, which are markedly expanded on the outer flank, and which appear to have terminated in an elongate, somewhat obliquely placed ven- 
tral clavus. One bulla gives rise to a pair of ribs, a total of seven ribs corresponding to six bullae on the specimen.

Remarks: The whorl section, simple ribbing, bullae and only slightly oblique setting of the ventral clavi characterize this fragment, and are very close to that of the lectotype of $O$. guersanti, refigured by Casey (1965, text-fig. $191 \mathrm{f}-\mathrm{g}$ ). $O$. guersanti semiglabrus Casey, 1965: 508, pl. 85, fig. 7, text-figs $187 \mathrm{f}, 192 \mathrm{~g}$ ) is more involute and has feeble dense ribs, effaced at mid-flank. The ornament of other simply ribbed species is generally weaker (e.g. O. oweni Casey, 1965: 509, pl. 85 , figs $2 \mathrm{a}-\mathrm{b}$ ) or ribs commonly arise in pairs (e.g. O. simplex Casey, 1965: 504, pl. 84, figs 3a-b; text-figs $187 \mathrm{c}, 192 \mathrm{j}-\mathrm{k}$ ). Other species are more inflated and/or show branching or lautiform ribbing (see Casey 1965: 491, et seq.).

Distribution: Otohoplites guersanti is known from the Protohoplites (Hemisonneratia) puzosianus and Otohoplites raulinianus Subzones of the Douvilliceras mammilatum Zone of England, and France south to Balme de Rencural (Isère), and may also occur as far east as Mangyshlak (fide Casey 1965: 508).

\section{Sonneratia Bayle, 1878}

Type species: Ammonites dutempleanus d'Orbigny, by monotypy.

Remarks: Casey (1965: 516-537) has provided a full discussion of this genus, and described eleven species and three varities, mainly strict contemporaries, from the English Lower Greensand. We are using his names, but we doubt that more than a few variable species are represented.

Distribution: Sonneratia is confined to the Douvilleiceras mammilatum Zone, with an acme in the basal part of the Zone. Its geographical extent is within the Hoplitinid Province, from Bornholm and England east to the Urals.

Sonneratia kitchini Spath, 1925

Pl. 3, figs 2a-c; pl. 4, figs 1a-b, 5a-c; pl. 5, figs $1 \mathrm{a}-\mathrm{b}, 5$.

Synonymy: Casey (1965: 521) has given a full synonymy of this species.
Material: MMH 2021 (the original of Ravn 1925, pl. 3, figs 7a-b), MGUH 15135-15138 and MM 1919.331.26, from the phosphatic conglomerate of the Arnager Greensand of Madsegrav, Bornholm.

Description: Our specimens are all phosphatic, and comprise two juveniles, a medium sized fragment (the original of Ravn's 1925, pl. 3, figs 7a-b, Parahoplites n.sp.) and several scraps of mature body chamber. In the juveniles (pl. 4, figs $1 \mathrm{a}-\mathrm{b})$ the whorl section is compressed, with the greatest breadth at or just outside the umbilical bulla. The inner flanks are rounded, the outer flanks flattened and convergent, the venter somewhat flattened. Ornament consists of blunt crowded ribs. These arise in pairs (or more rarely three's) from blunt umbilical bullae, whilst there are additional ribs intercalated low on the flank. All ribs are markedly flexuous, and are projected forwards and thickened across the venter to form a markedly convex peak. During middle growth (pl. 4, figs 5a-c), the sides flatten, whorl height increases, umbilical bullae weaken, whilst ribs flattende and broaden, especially on the inner flank. This trend continues on the largest available fragments (pl. 5, figs 1a-b).

Remarks: This series of specimens are referred to $S$. kitchini on the basis of whorl section, form and style of ribbing. All appear to belong to the restricted form of the species. S. kitchini chalensis Casey, 1965: 523, pl. 87, figs 4a-b; pl. 89, fig. 6) is more strongly ribbed at comparable sizes, and has better defined umbilical bullae. S. kitchini ovalis Casey, 1965: 524, pl. 88, figs $8 \mathrm{a}-\mathrm{b}$, text-fig. 198e) is also more strongly ribbed and has a compressed oval whorl section.

Distribution: Sonneratia kitchini is restricted to the lowest Subzone of the Douvilleiceras mammilatum Zone, to which it lends its name. It is best known from southern England, but occurs also in France, as at Machéroménil (Ardennes).

Sonneratia cf. rotator Casey, 1965

P1. 5, figs 3a-b.

Synonymy: See Casey (1965: 525). 
Material: MGUH 15139, from the phosphatic conglomerate of the Arnager Greensand of Madsegrav, Bornholm.

Description: The specimen is a worn phosphatic internal mould of a body chamber fragment with a whorl height of $29 \mathrm{~mm}$. The whorl section is depressed with the greatest breadth close to or at the umbilical bullae (the specimen is distorted). The inner flanks are swollen, outer flanks flattened and venter broadly rounded. Coarse, broad, flexuous proriradiate ribs arise in pairs from umbilical bullae; intercalated ribs are shorter or tenuously associated with a bulla. The ribs are flexed weakly forwards over the shoulder and venter, where they are markedly thicker.

Remarks: This fragment is compared to Sonneratia rotator Casey, 1965 : 525 , pl. 87 , figs $6 a-b$; pl. 89 , figs $4 \mathrm{a}-\mathrm{b}$; text-fig. 198f) on the basis of its depressed whorl section and coarse ribbing, which serve to distinguish it from the more depressed and finely ribbed $S$. perinflata Breistroffer (Casey 1965: 526, pl. 89, figs 2a-b, 3a-b; text-figs 197, 198a) and the even more depressed $S$. coronatiformis Luppov (see Casey 1965, text-fig. 196). Being immature, it is not possible to decide whether the specimen belongs to $S$. rotator sensu stricto, or the variety leightonensis Casey, 1965: 526, pl. 89, figs 1a-b) differentiated by its flat-sided body chamber with weakened ribbing.

Distribution: The species has been previously recorded from the Sonneratia kitchini Subzone of the Douvilleiceras mammilatum Zone of southern England, and from the undifferentiated $D$. mammilatum Zone of Machéroménil (Ardennes) and Ste. Croix (Switzerland).

\section{Sonneratia perinflata Breistroffer, 1947}

Pl. 4, figs 2a-b; fig. 5 .

Synonymy: Casey (1965: 526) has recently given a complete synonymy for this species.

Material: One specimen, MGUH 15140, from the phosphatic conglomerate of the Arnager Greensand at Madsegrav, Bornholm.

Description: The specimen is a phosphatized individual with an original diameter of perhaps 25 $\mathrm{mm}$. It retains phosphatized shell, and part at least of the outer whorl is body chamber. The inner whorls, extending back to protoconch, are preserved as phosphatized shell and siphuncle, and are free of sediment. Prosutures, protoconch and siphuncle are beautifully displayed (fig. 5). Coiling is very involute, with a small, crater-like umbilicus. The whorl section is very depressed, with a breadth to height ratio of 1.5 at the

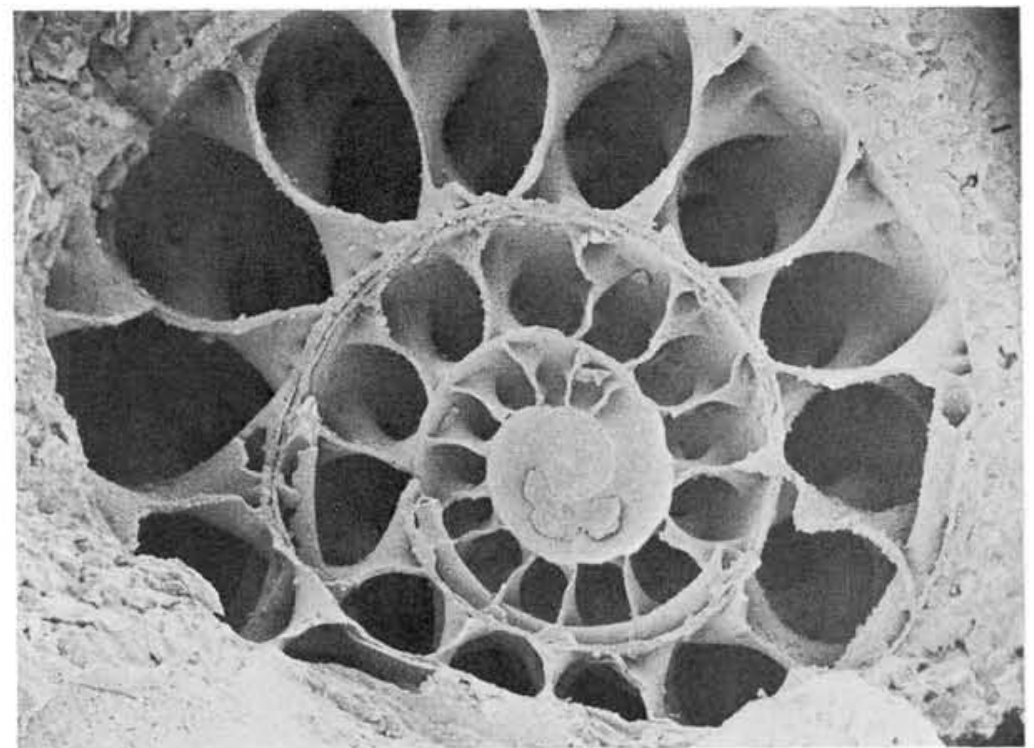

Fig. 5. Sonneratia perinflata Breistroffer, 1947. Early developmental stages of MGUH $15140, \times 12(\mathrm{see}$ also pl. 4, fig. 2). 
greatest diameter preserved, reniform, with the greatest breadth of the umbilical bulla. Ribs arise in two's or three's from bullae, with additional intercalated ribs. The ribs are projected forwards across the venter to give a distinctive ventral peak. No estimate of rib density is possible due to the fragmentary nature of the specimen.

Remarks: This juvenile Sonneratia is referred to $S$. perinflata on the basis of coiling, whorl section and ribbing, closely resembling the slightly larger West Derham example figured by Casey (1965, text-figs $197 \mathrm{c}, \mathrm{d})$. Whorl section and rib density in particular allow separation from $S$. kitchini Spath (e.g. Casey 1965, text-figs 195b-e), $S$. trigonalis Casey, 1965, pl. 88, figs $5 \mathrm{a}-\mathrm{b}), S$. elegans Casey, 1965, pl. 88, figs 7a-b) and $S$. rotator Casey and varieties (Casey 1965, pl. 89, figs $1 \mathrm{a}-\mathrm{b}, 4 \mathrm{a}-\mathrm{b}$ ). Sonneratia coronatiformis Luppov (1949: 245 , pl. 74 , figs $3 a-c)$ is a closely related species with a Cadoceras-like form at larger diameters; juveniles of similar size to our specimen are unknown, so that further discussion is not possible.

Distribution: Douvilleiceras mammilatum Zone, Sonneratia kitchini Subzone of southern England. Also known from the undifferentiated $D$. mammilatum Zone of Perte-du-Rhône (Ain) (Casey 1965, text-figs $197 \mathrm{a}-\mathrm{b})$.

Sonneratia species undetermined

Pl. 3, fig. 3; pl. 5, fig. 2; pl. 7, fig. 1.

Material: MGUH 15141-15142 and MM 1919. 331.21 , 1919.331.32, 1919.331.34, 1919.331. $37-38,1919.331 .42-46$, from the phosphatic conglomerate of the Arnager Greensand at Madsegrav, Bornholm.

Remarks: These twelve poorly preserved fragments are too incomplete to show whorl sections or details of ribbing style. They vary from quite markedly ribbed to almost smooth, and probably represent more than one species; the relative abundance of these poor fragments may be taken as indicative of the lower parts of the Douvilleiceras mammilatum Zone.

Sonneratia sp.?

Pl. 3, figs 4a-b; pl. 4, figs 3a-b.

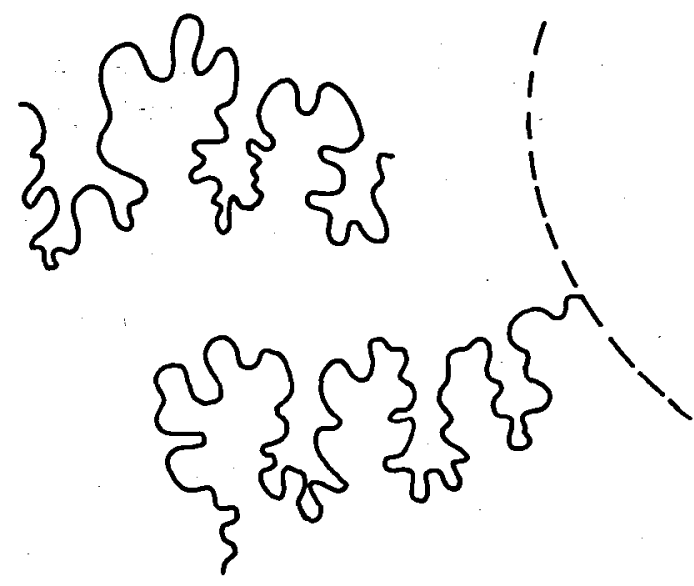

Fig. 6. Sonneratia sp. Partial suture of MMH 2023 showing details of the auxiliary elements on the suspensive lobe, $\times 6$.

Material: One specimen, MGUH 15143, from the phosphatic conglomerate of the Arnager Greensand at Madsegrav, Bornholm.

Description: This curious specimen differs markedly from all other Bornholm Sonneratia before us. Part of the nucleus is preserved (pl. 4, figs $3 a-b)$ and shows strongly convergent flanks and a narrowly rounded venter. Ornament consists of markedly prorsiradiate ribs which form a pronounced convex ventral peak. The body chamber fragment has a whorl height of approximately 35 $\mathrm{mm}$, with a compressed whorl section, with gently rounded inner flanks, flattened outer flanks, and a rounded venter. The specimen has suffered damage during life, and the ornament on one side is disturbed. Otherwise, body chamber ornament comprises irregular straight prorsiradiate ribs, weakly developed on the inner flank, and without bullae.

Remarks: The inner whorls of this specimen with convergent flanks and venter resembles some Sonneratia, e.g. S. trigonalis Casey, 1965: 533, pl. 88 , figs $5 \mathrm{a}-\mathrm{b}$ ). There are also similarities to some Cleoniceras and Pseudosonneratia, so that even generic assignation is uncertain.

Sonneratia umbilical moulds

Pl. 8, figs 3, 4; pl. 9, figs 6a-b; fig. 6.

1925 Kossmatella? sp. - Ravn: p. 43, pl. 4, figs 2, 6. 
Material: MMH 2027, MMH 2023, MGUH 15144-15145 and MM 1919.331.43-44, from the phosphatic conglomerate of the Arnager Greensand, Madsegrav, Bornholm.

Description: These specimens, including those figured by Ravn (1925, pl. 4, figs 2,6) are phosphatized umbilical moulds of involute ammonites with deep conical umbilici. Ornament consists of sparse rounded ribs, commonly twenty per whorl at the umbilicus, sometimes developed into bullae. One specimen (MMH 2023) shows details of the auxiliary elements on the umbilical lobe (fig. 6).

Remarks: These umbilical moulds are referred to Sonneratia by comparison with complete individuals before us; certainly they belong to a depressed, involute genus with a deep umbilicus. The specimen showing traces of the umbilical lobe has auxiliary elements like those shown by Sonneratia (e.g. Casey 1965: 531, text-figs $199 \mathrm{a}-\mathrm{c})$ - and indeed other hoplitids - but distinct from those of the gaudryceratid Kossmatella, which allow us to reject Ravn's determination with confidence.

Distribution: These specimens are indicative of nothing more precise than the Douvilleiceras mammilatum Zone, probably the lower parts.

Pseudosonneratia Spath, 1925

Type species: Pseudosonneratia typica Spath, by original designation.

Discussion: Casey (1965: 537-546) provides a complete diagnosis and review of the species referred to the genus, which forms the basis of our present observations.

Distribution: Pseudosonneratia is restricted to the Hoplitinid Faunal Province, ranging from Bornholm to southern England and south to France (especially Aube and Isère) and east to Transcaspasia.

Pseudosonneratia sp.

Pl. 3, figs $1 \mathrm{a}-\mathrm{b}$; pl. 5, figs 5a-b; pl. 6, figs $3,6 \mathrm{a}-\mathrm{b}$, pl. 7 , figs $2 a-b$.
1925 Parahoplites steinmanni Jacob - Ravn: p. 47 , pl. 3, figs 2, 4 .

Material: MGUH 15146-15150 and MM 1919.322.4, 1919.322.6, from the phosphatic conglomerate of the Arnager Greensand at Madsegrav, Bornholm.

Description: The material before us consists of poorly preserved worn phosphatic internal moulds, the best of which are figured. They are discoid ammonites with flat, slightly convergent sides and a flattened, feebly convex venter. The strong, flexuous primary ribs sweep forwards across the ventrolateral shoulders, and are broadly convex across the venter (pl. 6, figs $6 a-b)$. The ribs arise singly or in pairs from umbilical bullae, with occasional intercalated ribs also present. One specimen (pl. 3, figs 1a-b) shows a nucleus, which is still completely smooth at a diameter of $12 \mathrm{~mm}$.

Remarks: All these specimens are labelled Hoplites (Parahoplites) cf. steinmanni (Jacob), a Hoplites (Isohoplits), the lectotype of which has been re-illustrated by Casey (1965, text-figs 202a-d). Our specimens do not show the development of siphonal interruption to the ribbing which characterizes this subgenus, which is intermediate between Pseudosonneratia and Hoplites (Hoplites), and cannot, therefore be referred to $H$. (I). steinmanni. Because of poor preservation, it is difficult to identify our specimens fully with one or other of the ten named species of Pseudosonneratia, many of which are known only from poor fragments, although the inflated and strongly ribbed $P$. typica Spath (Casey 1965, text-figs 203a-b) and $P$. crassa Casey, 1965, text-figs 204c-d, Isohoplites-like $P$. laffrayei Breistroffer (Casey 1965, text-figs 203g-h) and acute-ventered $P$. acuta Casey, 1965 , pl. 90, figs $7 \mathrm{a}-\mathrm{b}$ ) can be eliminated from comparison.

Distribution: Pseudosonneratia species resembling our fragments are restricted to the Douvilleiceras mammilatum Zone; those more accurately dated are restricted to the Otohoplites raulinianus and Protohoplites (Hemisonneratia) puzosianus Subzones.

Pseudosonneratia occidentalis pluricostata Casey, 1965 ?

Pl. 6, fig. 2. 
1965 Pseudosonneratia occidentalis var. pluricostata Casey: p. 540, pl. 90, figs 6, 4a-b.

Material: MGUH 15151, from the phosphatic conglomerate of the Arnager Greensand, Madsegrav, Bornholm.

Description and remarks: This fragment is of a flat-sided planulate ammonite with dense flexuous bullate ribs. Some bullae give rise to pairs of ribs, and there is a suggestion of some intercalated ribs.

Although very poor, we have been struck by the resemblance of our fragment (labelled Hoplites (Parahoplites) cf. steinmanni) to Casey's variety pluricostata especially the holotype (Casey 1965, pl. 90, fig. 6). Because of poor preservation the comparison can only be tentative.

Distribution: Pseudosonneratia occidentalis pluricostata is known from the Otohoplites puzosianus and Protohoplites (Hemisonneratia) raulinianus Subzones of the Douvilleiceras mammilatum Zone of Kent, southern England.

Cleoniceratinae Whitehouse, 1926

Cleoniceras Parona \& Bonarelli, 1897

Type species: Ammonites cleon d'Orbigny, by original designation.

Remarks: Casey (1966: 553-574) provides the most comprehensive review of Cleoniceras (Cleoniceras) and the oxycone $C$. (Neosaynella) Casey, 1954.

Distribution: Cleoniceras first appears as a rarity in the middle of the Leymeriella tardefurcata Zone, and ranges to the base of the Middle Albian Hoplites dentatus Zone, with an acme (in Europe at least) in the Cleoniceras floridum Subzone of the Douvilleiceras mammilatum Zone. Geographically it extends from Bornholm to southern England, west through France and Germany to Transcaspasia and northwestern India, and south to Madagascar; and possibly Alaska and western Canada.

Cleoniceras species undetermined.

Pl. 8, figs 5a-b, 6, 7a-b; pl. 15, figs $1 \mathrm{a}-\mathrm{b}, 2 \mathrm{a}-\mathrm{b}$, $3 a-b, 4 a-b$.
1925 Desmoceras Beudanti Brongniart - Ravn: p. 44.

Material: MGUH 15152-15157 and MM 1919.322.10(?), 1919.332.12(?), from the phosphatic conglomerate of the Arnager Greensand, Madsegrav, Bornholm.

Description: Our specimens are poorly preserved body chambers of involute ammonites with a small deep umbilicus; flat, outwards sloping umbilical walls and an abruptly rounded umbilical shoulder. The whorl section is compressed, with flattened flanks converging to a broadly rounded venter. Ornament is poorly preserved, consisting of fine flexuous striae, sometimes bunched (pl. 8, figs $5 a-b, 6,7 a-b)$, or strengthened into near obsolete ribs.

Nuclei detached from these specimens (pl. 15, figs $2 \mathrm{a}-\mathrm{b} 4 \mathrm{a}-\mathrm{b}$ ) are, in contrast, compressed, high-whorled, with narrowly arched venters. The most complete shows distinctly flexuous strong ribs arising in pairs from umbilical bullae, with additional ribs intercalated (pl. 15, fig. 4b). The ribs are prorsiradiate, markedly convex on the inner flank, flexing backwards across mid-flank, concave on the outer flank, and markedly projected across the shoulder to form a narrowly convex central peak, with a distinct weakening of the ribs over the siphonal area.

Remarks: These poorly preserved, essentially smooth body chambers are labelled Desmoceras beaudanti, but the distinctive strong flexuous ribbing of the fragmentary inner whorls detached from them preclude reference to this genus. Instead, style, form and grouping of ribbing point to Cleoniceras, whilst the whorl section indicates the nominotypical subgenus rather than $C$. (Neosaynella). The incomplete nature of the nuclei (little more than the venter and outer flank is preserved in most) makes specific determination difficult, but the strongly ornamented nucleus of MGUH 15157 (pl. 15, figs 4a-b) might be compared with some species such as $C$. (C.) janneli (Parent) (e.g. Casey 1966, pl. 92, figs $2 \mathrm{a}-\mathrm{b}$ ) or $C$. (C.) seunesi Bonarelli (e.g. Casey 1966, pl. 92, figs 3a-b, $4 a-b, 8)$. Delicately ribbed nuclei such as those of MGUH 15154 (pl. 8, fig. 7) and MGUH 15156 (pl. 15, figs 2a-b), with more marked effacement of ventral ornament might equally be compared 
with species such as $C$. (C.) strigosum Casey, 1965, pl. 93, figs 6a-b).

Distribution: As noted in the generic diagnosis, the restricted subgenus is long ranging: the specimens from Bornholm probably represent some horizon high in the L. tardefurcata Zone or the $D$. mammilatum Zone.

\section{Cleoniceras sp.?}

Pl. 6, fig. 5 .

Material: One specimen, MGUH 15158, from the phosphatic conglomerate of the Arnager Greensand, Madsegrav, Bornholm.

Description: This large worn phosphatic specimen has a maximum whorl height of approximately $60 \mathrm{~mm}$. The whorl section is high, compressed, lanceolate, with a narrow, somewhat flattened (?) venter. Ornament consists of low ribs, accentuated and convex on the outer flank, and in some cases branching.

Remarks: The specimen is very poor indeed. It may perhaps be a large Cleoniceras like $C$. cleon (d'Orbigny) (compare Casey 1965, pl. 91, figs 5a-b, pl. 92,-figs 9a-b; pl. 93, fig. 1; text-fig. 211 ), but even this generic assignation is open to dispute.

\section{Anadesmoceras Casey, 1954}

Type species: Anadesmoceras strangulatum Casey, by monotype.

Remarks: Anadesmoceras comprises a group of involute discoidal cleoniceratids with a distinct but blunt umbilical rim, and feeble ornament of ribs and bunches of striae; many develop constrictions. Casey (1965) has recognized a series of closely related, morphologically intergrading 'species' which further study may show to represent no more than one or two variable species.

Distribution: Anadesmoceras has its acme in the Leymeriella tardefurcata Zone, $L$. regularis Subzone, a single species, $A$. baylei, surviving into the Douvilleiceras mammilatum Zone. Geographically, it is known from Bornholm, Jutland (ex Drift), England, France and western Canada.
Anadesmoceras costatum Casey, 1966

Pl. 7, fig. 3; pl. 8, figs 1a-c.

1925 Sonneratia Baylei Jacob - Ravn: p. 28 (pars.) pl. 3, figs 6a-b.

1966 Anadesmoceras costatum Casey: p. 578, pl. 96 , figs $1,2 \mathrm{a}-\mathrm{b}$; text-fig. $218 \mathrm{a}$ (with synonymy).

Material: MMH 2020 and MGUH 15159, from the phosphatic conglomerate of the Arnager Greensand, Madsegrav, Bornholm.

Description: MMH 2020, the original of Ravn's (1925, pl. 3, figs 6a-b) Sonneratia baylei, is an internal mould of less than half of whorl, with umbilicus well preserved and showing details of the inner whorls. Coiling is very involute, with a small, deep conical umbilicus. The umbilical shoulder is abruptly rounded, the whorl section compressed, lanceolate, with rounded flanks, the greatest breadth being low on the flanks, the venter narrowly rounded, but not acute. Low ribs arise at the umbilical seam, and sweep forwards to strengthen on the umbilical shoulder into distinct prorsiradiate bullae, thirteen to fourteen per whorl. These give rise to low, rounded, flexuous prorsiradiate ribs (pl. 8, fig. 1c), which flex forwards across the inner flank, backwards across the outer flank, and are projected markedly across the ventrolateral shoulders into a narrowly convex ventral peak. Between these primary ribs are inserted groups of intercalated ribs, indeterminate in number, together with numerous striae.

The second specimen referred to this species has weaker bullae and stronger ribs, but is otherwise closely similar.

Discussion: These two specimens are referred to Anadesmoceras costatum on the basis of the umbilical bullae and the strength and style of the ribbing. These suffice to distinguish it from the feebly ornamented Anadesmoceras subbaylei (Spath) (e.g. Casey 1966: 577, pl. 97, figs 6a-b), A. nudum Casey, 1966: 581, pl. 97, figs 7a-b), and $A$. tenus Casey, 1966: 579, pl. 96, figs 5a-b; text-fig. 218d). Anadesmoceras strangulatum Casey, 1966: 576, pl. 96, figs 3a-b, 4a-b; pl. 97, figs 2, 4, 5; text-figs $218 \mathrm{~b}$, f has almost smooth inner whorls, and is distinctly constricted.

Perhaps the closest comparisons are with $A$. baylei (Jacob), to which Ravn originally referred 
his specimens. Indeed, Casey (1966: 579) notes that the two can be separated only by the slightly weaker ribbing of the latter at the diameter of our specimens. MGUH 15159 is distinct enough in this respect, but MMH 2020, with weaker ribs, is somewhat transitional, although stronger bullae suggest $A$. costatum (compare Jacob 1908, pl. 7, figs 25a-b; also Casey 1966, pl. 95, fig. 1b). Differences are slight, however.

Distribution: Anadesmoceras costatum has been previously recorded only from the Leymeriella tardefurcata Zone, $L$. regularis Subzone of southern Engalnd.

Anadesmoceras cf. strangulatum Casey, 1954 PI. 7, figs $4 a-b$.

Compare: 1966 Anadesmoceras strangulatum Casey: p. 576, pl. 96, figs 3a-b, 4a-b; pl. 97, figs $2,4,5$; text-figs $218 \mathrm{~b}, \mathrm{f}$.

Material: MGUH 15160 and MM 1919.331.38, from the phosphatic conglomerate of the Arnager Greensand, Madsegrav, Bornholm.

Description: Our specimens comprise an almost complete body chamber (pl. 7, figs $4 a-b$ ) of a specimen estimated at over $100 \mathrm{~mm}$ diameter and a smaller fragment. The more complete specimen is involute, with a small, deep umbilicus. At the smaller end, the whorl section is compressed, with flattened convergent flanks and a narrowly rounded venter. At the aperture, the whorls are much broader, with swollen flanks, and a much broader, somewhat flattened venter. Ornament consists of obscure fold-like ribs at the back of the body chamber, and a broad, ill-defined constriction close to the aperture, succeeded by a marked rib. There are poorly defined striae and a further weak depression, scarcely a constriction, closer to the aperture.

Remarks: These specimens are poor worn fragments and reference to $A$. strangulatum must be regarded as speculative. Reasons for the assignation are chiefly the coiling, ontogenetic changes in whorl section (see Casey 1966, text-fig. 218b) and constrictions. It must be admitted that the latter are less distinct than in the type of $A$. strangulatum, whilst the poorly preserved ribs on our larger fragment might suggest it to be a transition form towards Anadesmoceras nudum (Casey 1966, pl. 97, figs 1a-b).

Distribution: A. strangulatum has been previously recorded only from the Leymeriella regularis Subzone of the $L$. tardefurcata Zone of southern England.

Anadesmoceras group of subbaylei (Spath, 1942) PI. 8, figs 2a-b.

Material: MGUH 15161, from the phosphatic conglomerate of the Arnager Greensand, Madsegrav, Bornholm.

Description: The specimen consists of a totally worn septate outer whorl with an estimated diameter of approximately $90 \mathrm{~mm}$, and part of a nucleus with maximum whorl height of $25 \mathrm{~mm}$.

The coiling is very involute, with a compressed, lanceolate whorl section, the greatest breadth low on the flanks, with a narrowly rounded venter. There are faint umbilical bullae which give rise to groups of delicate flexuous, slightly prorsiradiate striae.

Discussion: Weak bullae and flexuous striae in the combination shown by our specimen are seen in a number of Anadesmoceras at this size, e.g. Anadesmoceras strangulatum Casey (see, for instance Casey 1966, pl. 97, figs 3, 4), A. nudum Casey, 1966, pl. 97, figs 7a-b and $A$. tenue Casey, 1966, pl. 96, figs 5a-b, whilst $A$. subbaylei (Spath) may also be indistinguishable at this size, as Casey (1966: 577) has noted. As subbaylei is the oldest name applied to this group of feebly ribbed forms, it is applied to our specimen.

Distribution: Species with which our specimen is compared have been previously recorded only from the Leymeriella regularis Subzone of the $L$. tardefurcata Zone of southern England.

Schloenbachiidae Parona and Bonarelli, 1897 Schloenbachia Neumayr, 1875

Type species: Ammonites varians J." Sowerby, 1817 by the subsequent designation of $\mathrm{H}$. Douvillé (1890). 
Remarks: A monograph by Hancock on the Schloenbachia of England is in preparation, and this will shortly provide a full synonymy and discussion. It is a genus with a most appropriately named type species in that any one assemblage shows great variation, typically ranging from inflated individuals with strong tubercles, through moderately compressed varieties in which ribbing dominates over tuberculation, to strongly compressed almost smooth forms.

Ravn (1925) recognized five varieties amongst the Schloenbachia from the secondary nodules of the conglomeratic bed on Bornholm, but the knowledge of their stratigraphic range at that time was limited. He correctly considered $S$. coupei to be a Middle Cenomanian species, but he wrongly thought that $S$. varians ranged down into the Upper Albian.

The stratigraphical changes in Schloenbachia are small compared with the degree of variability at a single horizon. The specimens from the conglomeratic bed although phosphatized, are not well preserved and all are very incomplete. Hence it has been possible to use only one character in estimating their age: the relative strength of the umbilical and lower lateral tubercles. Since these small changes stratigraphically have to be related simultaneously to both the degree of inflation and ontogenetic stage of the individial, the estimate of age must be approximate and liable to error by the observer. The specimens from the main mass of the Arnager Greensand are usually distorted (and often crushed) and their ornament has been damaged: such specimens cannot be relied on for accurate zoning.

Distribution: Schloenbachia ranges from the Lower Cenomanian Zone of Hypoturrilites carcitanensis to the Upper Cenomanian Zone variously named after Eucalycoceras pentagonum or Calycoceras naviculare; it becomes less common upwards and died out below the top Cenomanian Zone of Sciponoceras gracile. As a hoplitid derivative, it is common and widespread in the Hoplitinid Faunal Province from East Greenland (Donovan 1954) to Mangyshlak (Semenov 1899), but also southwards into central Iran (Kennedy et al. 1979).

Schloenbachia varians varians (J. Sowerby, 1817) Pl. 10, figs $2 a-b$, pl. 11, figs $1 a-c$.
1817 Ammonites varians J. Sowerby: p. 226, pl. 176 , top figure.

1925 Schloenbachia coupei Brongniart - Ravn: p. 50 , pl. 3 , fig. 5 .

Material: MMH 2019, MGUH 15162, MM 1919.331.56, ?1919.322.15, from the phosphatic conglomerate of the Arnager Greensand, Madsegrav, Bornholm.

Description: Only the specimen previously figured by Ravn (1925, pl. 2, figs 5a-b) is at all well preserved. At this diameter of about $32 \mathrm{~mm}$ it shows the typically predominant tuberculate ornament of the species, with almost no trace of ribbing. That below the lower lateral tuberculation there are very weak ribs down to the edge of the umbilicus is an indication that this is a saxbii Zone specimen.

Schloenbachia varians aff. subtuberculata (Sharpe, 1853)

Pl. 10, figs $1 a-b$.

1853 Ammonites varians var. subtuberculata Sharpe: p. 22, pl. 8, figs 5a-c, 6a-b.

Material: MGUH 15163, from the phosphatic conglomerate of the Arnager Greensand, Madsegrav, Bornholm.

Remarks: The single specimen has relatively strong ribbing below the lower lateral tubercles. Indeed, the ribs begin abruptly at the umbilical edge with the trace of an umbilical tubercle. Such ornament is sufficient to indicate the saxbii or possibly dixoni Zones in spite of the incomplete and poor preservation of the specimen as a whole. Note the relatively inflated whorl at this small diameter compared with the lesser inflation of the larger lectotype and paralectotype figured by Sharpe.

Schloenbachia aff. varians varians (J. Sowerby, 1817)

Pl. 11, figs $7 a-c$.

Material: MGUH 15164, from the phosphatic conglomerate of the Arnager Greensand, Madsegrav, Bornholm. 
Remarks: This specimen is badly worn, but the strong inflation and dominantly tuberculate ornament place it in $S$. varians s.s. On the other hand, the strongish ribbing on the base of the sides ally it with $S$. coupei trituberculata Spath of the costatus Zone, and we would assign it to high in the dixoni Zone at the top of the Lower Cenomanian.

Schloenbachia varians subvarians Spath, 1926 Pl. 10, figs 3a-b, 5a-b, 9a-b, pl. 11, fig. 4.

1853 Ammonites varians var. intermedia Mantell - Sharpe: p. 23, pl. 8, figs 7a-b.

1925 Schloenbachia varians Sow. - Ravn: p. 50, pl. 4, fig. 5 .

Material: MMH 2026 and MGUH 1516515167 , from the phosphatic conglomerate of the Arnager Greensand.

Remarks: Schloenbachia varians subvarians is a form with sharply defined ribs and weakly developed tubercles on a strongly compressed whorl section at all but the earliest stage of ontogeny. The specimen figured by Ravn is the largest but least well preserved of the four specimens. All the other three show early development of umbilical tubercles indicating that they originate from some way up in the Lower Cenomanian, but as seen in MGUH 15166 (pl. 10, fig. 5b) they are not as strong as the lower lateral tubercles at this stage of ontogeny. Such forms are found in the saxbii and dixoni Zones.

Schloenbachia sp. cf. varians (J. Sowerby, 1817) Pl. 10, figs $4 a-b, 6 a-b, 7 a-b$, pl. 11, figs $2 a-b, 3$.

Material: MMH 1919, MGUH 15168-15173 and MM 1919.331.52, 1919.331.54, 1919. 331.63 and 1919.331.17-18, from the phosphatic conglomerate of the Arnager Greensand, Madsegrav, Bornholm.

Remarks: These eleven specimens of Schloenbachia from the conglomerate are too poorly preserved for specific identification, but six of them are figured to show the general variation. On the assumption that the Schloenbachia-assemblage of the basal conglomerate is wholly Lower Cenomanian, they mostly range from $S$. varians s.s. to $S$. varians subvarians.
Schloenbachia ?coupei (Brongniart, 1822)

1822 Ammonites Coupei Brongniart: p. 606, pl. 6 , figs $3 a-c$.

Material: MM 1917.151 from the Arnager Greensand, Bornholm.

Remarks: This inflated specimen is undistorted byt poorly preserved. Nevertheless, the distinctly strong ribbing immediately above the umbilical edge at so early an ontogenetic stage of an inflated Schloenbachia, indicates a Middle Cenomanian age.

Schloenbachia coupei (Brongniart, 1822) var. nov. A

P1. 12, figs $2 a-c$.

Material: MGUH 15174, from the Arnager Greensand, Bornholm, preserved as a distorted internal mould with traces of shell.

Remarks: This variety of $S$. coupei is a Middle Cenomanian equivalent of an intermediate between $S$. varians subtuberculata and $S$. varians subvarians. The specimen is badly distorted by crushing perpendicular to the diameter, but the ornament is relatively undamaged. Nevertheless, the preponderance of ribbing over tuberculation in the earlier part of the individual, and of equal tuberculation and ribbing on the later part, have been falsely emphasized by the crusing.

There are distinct tubercles on the umbilical edge, but they are still weaker than the lower lateral tubercles at the youngest stage preserved, which would indicate costatus Zone.

Schloenbachia coupei (Brongniart, 1822) var. nov. B

PI. 12, figs $4 a-b$.

Material: MGUH 15175 from the Arnager Greensand of Bornholm, preserved as an undistorted internal mould.

Remarks: This very fragmentary specimen is a Middle Cenomanian equivalent of $S$. varians ventriosa Stieler. In spite of the poor preservation, it is possible to make out weak ribs beneath the lower lateral tubercles, and it is probably a costatus Zone form. 
Schloenbachia sp. cf. coupei (Brongniart, 1822) Pl. 11, figs 5 and 8, pl. 12, figs 3a-b.

1916 Schloenbachia varians Sow. - Ravn: p. 3, pl. 5, figs 3a-b, ?fig. 4.

1916 Schloenbachia Coupei Brongn. - Ravn: p. 31 , pl. 5, figs 5a-c.

Material: MMH 1539-1540, MGUH 15176 and MM 1915.104a, 1915.104b from the Arnager Greensand, Bornholm.

Remarks: Several of these specimens are moderately well preserved but distorted to an extent that makes specific identification difficult. $\mathrm{MMH}$ 1539 (pl. 12, fig. 3 ) is probably close to $S$. coupei s.s.; it combines strong lateral tubercles with exceptionally weak umbilical tubercles, but the two would probably exchange relative prominence rapidly during later ontogeny, which would indicate some affinity with $S$. devonensis Spath of the Middle Cenomanian. MGUH 15176 (pl. 11, fig. 5 ) is probably $S$. coupei var. nov. B, but, even allowing for the obvious distortion, the extreme weakness of the ribs below the lower lateral tubercles would usually suggest a Lower Cenomanian form. MMH 1540 (pl. 11, fig. 8) could also be from high in the Lower Cenomanian or low in the Middle Cenomanian.

Acanthocerataceae Hyatt, 1900

Leymeriellidae Breistroffer, 1951

Leymeriella Jacob, 1907

Type species: Ammonites tardefurcatus (d'Orbigny ex Leymerie MS), by the subsequent designation of Spath, 1925.

Remarks: Casey (1957) provided an exhaustive account of the British species of Leymeriella and its extra British relatives, together with the suggestion that the genus, and the subfamily Leymeriellinae, should be transferred to the Lyelliceratidae. Subsequently Wright (1955) raised Breistroffer's subfamily to family rank, a status now agreed by Casey (1978). More than a score of Leymeriella species have been described from Europe, no less than eighteen of them from a single subzone. We doubt that this degree of splitting can be justified in such a close-knit group, and believe that a re-investigation of the rich German faunas will show that many of these named forms are no more than intraspecific variants. However, because the material before us is poor and fragmentary, we have accepted current species limits in full cognaisance of their artificial limits.

Distribution: Leymeriella is restricted to the Hoplitinid Faunal Province, extending from Bornholm to Greenland, Jutland (ex drift: see Skeat \& Madsen, 1898), England, France south to Balme de Rencurel and the Escragnolles area, Switzerland and Germany, east to Bulgaria, the Urals, and Iran. Stratigraphically, the genus is restricted to the milletioides and regularis Subzones of the tardefurcata Zone of the English sequence.

\section{Leymeriella (Neoleymeriella) Savelier, 1973}

Type species: Leymeriella consueta Casey, 1957.

Leymeriella (Neoleymeriella) regularis (Brugière), 1780

Pl. 9, fig. 1.

1925 Hoplites (Leymeriella) regularis Brug. sp. Ravn: p. 45, pl. 3, fig. 3.

1957 Leymeriella (Leymeriella) regularis (Brugière) d'Orbigny sp. - Casey: p. 49, pl. 8, figs 5-5b, 9-9a; pl. 9, fig. 2; pl. 10, fig. 7.

1978 Leymeriella (Neoleymeriella) regularis (Brugière) d'Orbigny sp. - Casey: p. 607, pl. 98, figs 1a-b, 2; pl. 99, figs $9,10 a-b$; text-fig $230 a-b$, d-h. (with full synonymy).

Material: MMH 2017, and possibly MM 1919.331.8, from the phosphatic conglomerate of the Arnager Greensand, Madsegrav, Bornhom.

Description: The better preserved example (pl. 9, fig. 1) is an internal mould, originally figured by Ravn (1925, pl. 3, figs 3a-b). It consists of part of a specimen with a nucleus of $23 \mathrm{~mm}$ estimated diameter and a body chamber with a maximum whorl height of $17-18 \mathrm{~mm}$. The coiling is moderately evolute, with a broad shallow umbilicus with an outwards sloping wall of moderate height, a rounded shoulder, flanks which are gently swollen below (the greatest breadth is close to the umbilical bulla), converging towards the venter in 
intercostal section, although the outer flanks are distinctly concave in costal section. The venter is quite narrow and flattened in intercostal section, but rounded and concave between ventral clavi.

On the nucleus, there are 23-24 ribs per whorl, which arise at the umbilical seam. They pass forwards across the umbilical wall, strengthening into umbilical bullae. From these, distinctly flexuous prorsiradiate ribs arise, strengthening and coarsening as diameter increases. They sweep forwards across the umbilical shoulder, are convex across the inner flank, flexing backwards across mid flank, and are concave on the outer flank, projecting forwards to terminate in strong, high, obliquely placed outwards projected forwards to terminate in strong, high, obliquely placed outwards projected ventral clavi on either side of the concave venter. These decline towards the siphonal line, but nevertheless form a distinctive ventral chevron.

After strengthening markedly at $16-17 \mathrm{~mm}$ to almost the end of the outer whorl, the last four ribs are substantially weakened.

The sutures are not visible.

The second specimen tentatively referred to this species, MM 1919.331.8, is an umbilical mould showing a rather similar style of ornament, especially in terms of the ontogenetic changes of rib style and development.

Remarks: The figured specimen is in close agreement with the neotype of the species designated and figured by Casey (1957, pl. 8, figs. 5a-b), although larger. It is much more coarsely ribbed than Leymeriella (Leymeriella) tardefurcata, has more prominent clavi, and lacks the distinctive expansion of the outer part of the ribs into flattened sulcate wedges.

$L$. (N.) rudis Casey, 1957: 54, pl. 7, fig. 10; pl. 8 , figs $6 a-b$ is much more inflated, coarsely and grossly ribbed, with a depressed polygonal whorl section. The same is true of the strongly ribbed, spinose L. (L.) diabolus Casey, 1965: 56, pl. 9, figs $6 \mathrm{a}-\mathrm{b}$.

Leymeriella (Neoleymeriella) pseudoregularis Seitz, 1930: 24, pl. 5, fig. 3; see also Casey 1957: 52 , pl. 10 , fig. 1 is a more closely comparable species, commonly confused with $L$. (N.) regularis. It is more evolute with a wider umbilicus, with weaker bullae and less flexuous ribs than our specimen. Inner ribs are more coarsely ornamented.

L. (N.) consueta Casey, 1957: 53, pl. 9, figs $8-8 \mathrm{a}$; pl. 10 , figs $5-5 \mathrm{~b}, 13$; text-figs $1 \mathrm{a}-\mathrm{h}$ is also similar. It differs, however, in having umbilical spines, more prominent ventral clavi and fatter whorls.

Distribution: This species is widespread in western Europe, being known from Bornholm, England, many areas in France (especially the Ardennes, and south to La Balme de Rencurel and Escragnolles, La Goudinière in Haute Savoie), Germany (especially Hannover), Jutland (ex drift) and areas as far east as Iran.

Leymeriella spp. undetermined

Pl. 5, figs 6a-b; pl. 9, fig. 3.

Material: Two specimens MGUH 15178-15179, from the phosphatic conglomerate of the Arnager Greensand near Madsegrav, Bornholm.

Description: The smaller fragment MGUH 15179 (pl. 9, fig. 3), is an umbilical mould of a Leymeriella with a maximum diameter of approximately $23 \mathrm{~mm}$, and about twenty eight ribs per whorl. The larger specimen, MGUH 15178 (pl. 5, figs 6a-b), is a larger body chamber fragment with a maximum whorl height of $28-30 \mathrm{~mm}$ (estimated). The whorl section is compressed, with flattened flanks. The fragment bears eleven strong, crowded flaxuous ribs of variable strength, arising from umbilical bullae, and broadening markedly on the middle of the flanks. Occasional interspaces are strengthened into constriction-like depressions.

Both these fragments are too poor to be determined with confidence.

Distribution: These fragments suggest nothing more precise than the higher subzones of the Leymeriella tardefurcata Zone.

Epileymeriella Breistroffer, 1947

Type species: Hoplites (Parahoplites) hitzeli Jacob, by the original designation of Breistroffer, 1947. 
Remarks: L. (Epileymeriella) differs from the nominotypical subgenus chiefly in that the ribs branch from weak umbilical bullae.

Distribution: The subgenus is apparently restricted to the Leymeriella regularis Subzone of the L. tardefurcata Zone of western Europe.

Epileymeriella (Epileymeriella) hitzeli (Jacob, 1908)

Pl. 2, fig. 3?; pl. 9, figs 2, 4, 5 .

1908 Hoplites (Parahoplites) hitzeli Jacob: p. 48, pl. 8, figs 1a-b, 3a-b.

1924 Leymeriella cf. hitzeli (Jacob) - Spath: p. 83.

1925 Parahoplites hitzeli Jacob - Ravn: p. 47, pl. 4, fig. 3.

1937 Leymeriella hitzeli Jacob - Brinkmann: p. 14 et seq.

1947 Epileymeriella hitzeli (Jacob) - Breistroffer: p. 71.

1957 Leymeriella (Epileymeriella) sp. cf. hitzeli (Jacob) - Casey: p. 57, pl. 9, figs 5a-b.

1978 Epileymeriella (Epileymeriella) sp. cf. hitzeli (Jacob) - Casey: p. 620, pl. 99, figs 8a-b; text-fig. 236.

Material: MMH 2024, MGUH 15180-15182 and MM 1919.331.16-17, all from the phosphatic conglomerate of the Arnager Greensand at Madsegrav, Bornholm.

Description: The best specimen, described and figured by Ravn (1925, pl. 4, fig. 3), is wholly septate, with an estimated original diameter of approximately $40 \mathrm{~mm}$. The umbilicus is shallow, with a low subvertical wall, which increases in height markedly at the greatest diameter. The flanks are flattened, apparently compressed, with the greatest breadth just outside the umbilical shoulder. There are twenty-five ribs on the outer whorl. These arise just above the umbilical seam, sweep forwards across the umbilical wall to sharp elongate bullae. The ribs flex markedly across the flank and are convex close to the umbilical shoulder but concave at mid-flank, and are strongly projected across the ventrolateral shoulder. Narrow at the umbilicus, the ribs broaden and flatten on the outer flank and are grooved, to give a distinctive bifurcate appearance. At the largest preserved diameter the ribs strengthen markedly, and some interspaces deepen into clear constrictions.

Remarks: These specimens, almost all umbilical moulds, show the typical coiling and branching ribbing of Jacob's 'Hoplites' hitzeli, and we confirm Ravn's record.

Distribution: This species is recorded from Germany, southern England and south-eastern France, where it is taken as an indicator of the Leymeriella regularis Zone; the most precisely dated material is from the $L$. tardefurcata Subzone.

Acanthoceratidae Hyatt, 1900

Acanthoceratinae Hyatt, 1900

Acanthoceras Neymayr, 1875

Type species: Ammonites Rhotomagensis Brongniart 1822 , by the subsequent designation of De Grossouvre (1894).

Remarks: The reader is referred to recent works on this genus by Kennedy \& Hancock (1970), Kennedy (1971) and Juignet \& Kennedy (1977) for diagnosis and discussion of this well-known genus, as well as a commentary on the various subgenera proposed by Thomel (1972).

Distribution: Acanthoceras ranges throughout the Middle Cenomanian, and into the lower parts of the Upper Cenomanian. Its geographic distribution extends to western Europe, the U.S.S.R., Iran, the Middle East, north Africa, Nigeria, Angola, South Africa, Mozambique, Japan, southern India, Peru, Texas and the U.S. Western Interior.

Acanthoceras rhotomagense (Brongniart) sussexiense (Mantell)

Pl. 13; pl. 14.

1822 Ammonites sussexiensis Mantell: pp. 114-115, pl. 20, fig. 2.

1945 Acanthoceras aff. sherboni Spath - Rosenkrantz: p. 441, figs 1a-b.

1970 Acanthoceras rhotomagense var. sussexiense (Mantell) - Kennedy \& Hancock: p. 472, pl. 89, 
fig. 2 ; pl. 91, figs $1-2 ;$ pl. 92 , figs $1-2$; text-figs 3 , 4, 5, 6a (with synonymy).

1977 Acanthoceras rhotomagense sussexiense (Mantell) - Juignet \& Kennedy: p. 116, pl. 30, figs 2 , 4a-b (with synonymy).

Material: Two specimens; MGUH 15183 and MMH 5163, both from the Arnager Greensand of Madsegrav, Bornholm. Both are composite moulds in glauconitic sandstone.

Description: Both specimens are fragmentary composite internal moulds of large Acanthoceras. The coiling is evolute, the lower ventrolateral tubercle of each whorl being visible in the umbilicus of the succeeding one, housed in a notch in the umbilical wall. Ornament comprises an estimated twenty ribs per whorl, straight and rursi-to rectiradiate. All are long, and bear strong umbilical bullae and conical lower ventrolateral tubercles, connected by strong ribs; the venter of the large specimen (MMH 5163) is abraded, but it also appears to belong to the same form.

Discussion: The presence of strong ribs and tubercles plus lack of shorter intercalated ribs clearly point to the robust variants of Acanthoceras rhotomagense, in particular Mantell's sussexiensis; although the specimens are in some respects transitional to Gueranger's confusum. $A$. jukesbrownei (Spath) has alternately long and short ribs throughout ontogeny, whilst $A$. hippocastanum (J. de C. Sowerby) is a much smaller, globose species. $A$. sherboni, with which Rosenkrantz compared his specimen, is less inflated, more distantly ribbed, and lacks the prominent tubercles of the specimens before us.

Distribution: Acanthoceras rhotomagense sussexiense is best known from England and France, where it characterizes the top of the Turrilites costatus Zone and the succeeding Turrilites acutus Zone.

Related forms survive into the base of the Upper Cenomanian, but are rare.

Acknowledgement. The Geological Institute, University of Copenhagen is thanked for permission to use the scanning electron microscope of the Laboratory of Electron Microscopy.

\section{Dansk sammendrag}

Ammonitterne fra Arnager Grønsandet og dets konglomerat på Bornholm er blevet revideret. Tre tidsintervaller er reprasenteret $i$ det fosfatiske konglomerat. Ammonitterne fra primærknoldene reprasenterer to tidsintervaller i Nedre Albian. Ammonitterne fra matrix af sekundærknoldene er fra Nedre Cenomanian og Amager Grønsandet sensu stricto kan henføres til den nedre del af Mellem Cenomanian på basis af ammonitter og planktiske foraminiferer. De eustatiske havniveauændringer på Bornholm i det mellemste kridt er skitseret.

\section{References}

Baartman, J. C. \& Christensen, O. B. 1975: Contributions to the interpretation of the Fennoscandian Border Zone. Danm. geol. Unders. (2) 102, 47 pp.

Birkelund, T. 1957: Upper Cretaceous belemnites from Denmark. Biol. Skr. dan. Vid. Selsk. 9(1), 69 pp.

Breistroffer, M. 1947: Sur les zones d'ammonites dans l'Albien de France de d'Angleterre. Trav. Lab. Géol. Univ. Grenoble $26,1-88$.

Brinkmann, R. 1937: Biostratigraphie des Leymeriellenstammes nebst Bemerkungen zur Paläogeographie des Nordwestdeutschen Alb. Mitt. geol. Inst. Hamburg 16, 1-18.

Bromley, R. G. 1979: Field meeting in southern Scandinavia 18-28 September 1975. Proc. Geol. Ass. 90, 181-191.

Carter, D. J. \& Hart, M. B. 1977: Aspects of mid-Cretaceous stratigraphical micropalaeontology. Bull. Br. Mus. nat. Hist. (Geol.) 29, 1-135.

Casey, R. 1952: The ammonite genera Arcthoplites Spath and Tetrahoplites gen. nov. Proc. geol. Soc. Lond. 1490 , 134-135.

Casey, R. 1957: The Cretaceous ammonite genus Leymeriella, with a systematic account of its British occurrences. Palaeontology 1, 29-59.

Casey, R. 1965: A monograph of the Ammonoidea of the Lower Greensand, part 6. Palaeontogr. Soc. (Monogr.), 399-546.

Casey, R. 1966: A monograph of the Ammonoidea of the Lower Greensand, part 7. Palaeontogr. Soc. (Monogr.), $547-582$.

Casey, R. 1978: A monograph of the Ammonoidea of the Lower Greensand, part 8. Palaeontogr. Soc. (Monogr.), $583-632$.

Christensen, O. B. 1972: Det danske sankningsområdes udvikling i det mellemste Mesozoikum. Dansk geol. Foren., Arsskrifi for 1971, 55-62.

Christensen, W. K. 1973: The belemnites and their stratigraphical significance. In: Bergström, J., Christensen, W. K., Johansson, C. \& Norling, E.: An extension of Upper Cretaceous Rocks to the Swedish west coast at Särdal. Bull. geol. Soc. Denmark 22, 113-140.

Christensen, W. K. 1978: The Mid-Cretaceous of Scandinavia. Anns Mus. Hist. Nat. Nice 4, 6 pp.

Collignon, M. 1964: Atlas des fossiles characteristiques de Madagascar (Ammonites) 11 (Cénomanien), $152 \mathrm{pp}$. Tananarive, Service Géologique.

Cooper, M. R. 1977: Eustacy during the Cretaceous: its implications and importance. Palaeogeogr., Palaeoclimatol., Palaeoecol. 22, 1-60.

Curray, J. R. 1964: Transgressions and regressions. In: Miller, R. L. (Ed.): Papers in marine geology (Shepard commemorative volume) 175-203. New York, Macmillan.

Diener, C. 1925: Fossilium Catalogus 1: Animalia 29 (Ammonoidea neocretacea), 244 pp. Berlin, Junk. 
Donovan, D. T. 1954: Upper Cretaceous fossils from Traill and Geographical Society Øer, East Greenland. Meddr Grønland 72(6), $33 \mathrm{pp}$.

Donovan, D. T. \& Jones, E. J. W. 1979: Causes of world-wide changes in sea level. Jl. geol. Soc. Lond. 136, 187-192.

Douglas, R. G. \& Rankin, C. 1969: Cretaceous planktonic Foraminifera from Bornholm and their zoogeographic significance. Lethaia 2, 185-217.

Douvillé, H. 1890: Sur la classification des Cératites de la Craie. Bull. Soc. géol. Fr. (3) 18, 275-292.

Grossouvre, A. de 1894: Recherches sur la Craie Supérieure 2: Les ammonites de la Craie Supérieure. Mêm. Carte géol. dét. Fr. 264 pp.

Gry, H. 1960: Geology of Bornholm. Int. geol. Congr. 21 (Norden), Excursion Guide A45 \& C40, 3-16.

Hallam, A. 1978: Eustatic cycles in the Jurassic. Palaeogeogr., Palaeoclimatol., Palaeoecol. 23, 1-32.

Hancock, J. M. \& Kauffman, E. G. 1979: The great transgressions of the Late Cretaceous. Jl. geol. Soc. Lond. 136, 175-186.

Hart, M. B. 1979: Biostratigraphy and palaeozoogeography of planktonic Foraminiferida from the Cenomanian of Bomholm, Denmark. Newsl. Stratigr. 8, 83-96.

Hart, M. B. \& Tarling, D. H. 1974: Cenomanian palaeogeography in the north Atlantic and possible mid-Cenomanian eustatic movements and their implications. Palaeogeogr., Palaeoclimatol., Palaeoecol. 15, 95-108.

Hinte, J. E. van 1976: A Cretaceous time scale. Bull. Am. Ass. Petrol. Geol. 60, 498-516.

Jacob, C. 1908: Études sur quelques ammonites du Crétacé moyen. Mém. Soc. géol. Fr. Paléont. 15(38), 1-64.

Jeletzky, J. A. 1978: Causes of Cretaceous oscillations of sea level in western and Arctic Canada and some general geotectonic implications. Geol. Surv. Canada Pap. 77-18, $44 \mathrm{pp}$.

Juignet, P. \& Kennedy, W. J. 1977: Faunes d'Ammonites et biostratigraphie comparée du Cénomanien du nord-ouest de la France (Normandie) et du sud de l'Angleterre. Bull. trimest. Soc. géol. Normandie Amis Mus. Havre 63(2), 193 pp. (mis-dated 1976).

Kennedy, W. J. 1971: Cenomanian ammonites from southern England. Spec. Pap. Palaeont. 8, 133 pp.

Kennedy, W. J., Chahida, M. R. \& Djafarian, M. A. 1979: Cenomanian cephalopods from the glauconitic limestone southeast of Esfahan, Iran. Acta palaeont. Pol. 24, 3-5.

Kennedy, W. J. \& Hancock, J. M. 1970: Ammonites of the genus Acanthoceras from the Cenomanian of Rouen, France. Palaeontology 13, 462-490.

Kennedy, W. J. \& Hancock, J. M. 1978: The Mid-Cretaceous of the United Kingdom. Anns Mus. Hist. Nat. Nice 4, 72 pp.

Mantell, G. 1822: The fossils of the South Downs; or illustrations of the geology of Sussex. 327 pp. London.
Matsumoto, T. 1977: On the so-called Cretaceous transgressions. Spec. Pap. palaeont. Soc. Japan 21, 75-84.

Orbigny, A. d' 1840-42: Paléontologie Française. Description des Mollusques rayonnés fossiles. Terrain Crétacés 1 (Céphalopodes), 662 pp. Paris, Victor Masson.

Owen, H. G. 1971: Middle Albian stratigraphy in the AngloParis Basin. Bull. Brit. Mus. nat. Hist. (Geol.). suppl. 8, $164 \mathrm{pp}$.

Pictet, F. J. \& Campiche, G. 1858-64: Description des fossiles du terrain crétacé des environs de Sainte-Croix. Matériaux pour la paléontologie suisse (2) 2(2), 29-380.

Ravn, J. P. J. 1916: Kridtaflejringerne paa Bornholms Sydvestkyst og deres Fauna. 1. Cenomanet. Danm. geol. Unders. (2) $30,40 \mathrm{pp}$.

Ravn, J. P. J. 1925: Det cenomane Basalkonglomerat paa Bornholm. Danm. geol. Unders. (2) 42, 64 pp.

Reyment, R. A. 1955: The Cretaceous Ammonoidea of southern Nigeria and the southern Cameroons. Bull. geol. Surv. Nigeria 25, 112 pp.

Rosenkrantz, A. 1945: Småbidrag til Danmarks Geologi 1-8. 2. Nye Ammonitfund i Kridtformationen paa Bornholm. Meddr dansk geol. Foren. 10, 436-459.

Seitz, O. 1930: Zur Morphologie der Ammoniten aus dem Albien. Jb. preuss. geol. Landesanst. BergAkad. 51, 8-35.

Semenov, B. 1899: Faune des dépôts crétacés de Manguchlak et de quelques autres localités de la province Transcaspienne. Trudỹ imp. S.-Peterb. Obshch. Estest. 28, 1-178. (in Russian).

Sharpe, D. 1853-57: Description of the fossil remains of Mollusca found in the Chalk of England. Cephalopoda. Palaeontogr. Soc. (Monogr.) $68 \mathrm{pp}$.

Skeat, E. \& Madsen, V. 1898: On Jurassic, Neocomian and Gault boulders found in Denmark. Danm. geol. Unders. (2) 8,213 pp.

Sornay, J. 1956: Turrilites desnoyersi. Palaeont. univers. (n.s.) fiche 10.

Sowerby, J. 1815-18: The Mineral Conchology of Great Britain 2, pls. 103-203. London.

Spath, L. F. 1924: On the ammonites of the Speeton Clay and the subdivisions of the Neocomian. Geol. Mag. 61, 73-89.

Spath, L. F. 1925: A monograph of the Ammonoidea of the Gault, part 2. Palaeontogr. Soc. (Monogr.) 73-110.

Stenestad, E. 1972: Træk af det danske bassins udvikling i Øvre Kridt. Bull. geol. Soc. Denmark 21, 63-69.

Thomel, G. 1972: Les Acanthoceratidae cénomaniens des chaines subalpines méridionales. Mém. Soc. géol. Fr. (n.s.) 51 (116), $204 \mathrm{pp}$.

Wiedmann, J. 1962: Ammoniten aus der vascogotischen Kreide (Nordspanien). I. Phylloceratine, Lytoceratina. Palaeontographica (A) 118, 119-237.

Wright, C. W. 1955: Notes on Cretaceous ammonites - II. The phylogeny of the Desmocerataceae and the Hoplitaceae. Ann. Mag. nat. Hist. (12) 8, 561-575. 